\title{
Glutamatergic Transmission to Hypothalamic Kisspeptin Neurons Is Differentially Regulated by Estradiol through Estrogen Receptor $\alpha$ in Adult Female Mice
}

\author{
는 \\ and Suzanne M. Moenter ${ }^{1,2,3}$ \\ Departments of ${ }^{1}$ Molecular and Integrative Physiology, ${ }^{2}$ Obstetrics and Gynecology, ${ }^{3}$ Internal Medicine, ${ }^{4}$ Neuroscience Graduate Program, and ${ }^{5}$ Michigan \\ Diabetes Research \& Training Center, University of Michigan, Ann Arbor, Michigan 48109
}

Estradiol feedback regulates gonadotropin-releasing hormone $(\mathrm{GnRH})$ neurons and subsequent luteinizing hormone (LH) release. Estradiol acts via estrogen receptor $\alpha(\mathrm{ER} \alpha)$-expressing afferents of GnRH neurons, including kisspeptin neurons in the anteroventral periventricular (AVPV) and arcuate nuclei, providing homeostatic feedback on episodic GnRH/LH release as well as positive feedback to control ovulation. Ionotropic glutamate receptors are important for estradiol feedback, but it is not known where they fit in the circuitry. Estradiol-negative feedback decreased glutamatergic transmission to AVPV and increased it to arcuate kisspeptin neurons; positive feedback had the opposite effect. Deletion of ER $\alpha$ in kisspeptin cells decreased glutamate transmission to AVPV neurons and markedly increased it to arcuate kisspeptin neurons, which also exhibited increased spontaneous firing rate. KERKO mice had increased LH pulse frequency, indicating loss of negative feedback. These observations indicate that $\mathrm{ER} \alpha$ in kisspeptin cells is required for appropriate differential regulation of these neurons and neuroendocrine output by estradiol.

Key words: estradiol feedback; estrogen receptor alpha; glutamatergic transmission; GnRH; kisspeptin; LH pulse

Significance Statement

The brain regulates fertility through gonadotropin-releasing hormone $(\mathrm{GnRH})$ neurons. Ovarian estradiol regulates the pattern of $\mathrm{GnRH}$ (negative feedback) and initiates a surge of release that triggers ovulation (positive feedback). GnRH neurons do not express the estrogen receptor needed for feedback (estrogen receptor $\alpha[E R \alpha]$ ); kisspeptin neurons in the arcuate and anteroventral periventricular nuclei are postulated to mediate negative and positive feedback, respectively. Here we extend the network through which feedback is mediated by demonstrating that glutamatergic transmission to these kisspeptin populations is differentially regulated during the reproductive cycle and by estradiol. Electrophysiological and in vivo hormone profile experiments on kisspeptin-specific $\mathrm{ER} \alpha$ knock-out mice demonstrate that $\mathrm{ER} \alpha$ in kisspeptin cells is required for appropriate differential regulation of these neurons and for neuroendocrine output.

\section{Introduction}

Gonadotropin-releasing hormone $(\mathrm{GnRH})$ neurons form the final common pathway for central regulation of fertility. GnRH stimulates the pituitary to secrete the gonadotropins, follicle-

\section{Received Aug. 24, 2017; revised Sept. 28, 2017; accepted 0ct. 30, 2017.}

Author contributions: L.W., L.L.B., and S.M.M. designed research; L.W. performed research; M.L.G.-Y. and M.G.M. contributed unpublished reagents/analytic tools; L.W., L.L.B., and S.M.M. analyzed data; L.W., L.L.B., and S.M.M. wrote the paper.

This work was supported by National Institute of Health/Eunice Kennedy Shriver National Institute of Child Health and Human Development R01 HD41469 to S.M.M., P50 HD28934 (University of Virginia Assay Core), and National Institute of Diabetes and Digestive and Kidney Diseases R01 DK057768 to M.G.M. We thank Elizabeth R. Wagenmaker for expert technical assistance; the University of Virginia Center for Research in Reproduction Ligand and Assay Core for conducting hormone measurements; and James L. Kenyon (University of Nevada, Reno, NV) for the Excel spreadsheet used to calculate junction potentials.

The authors declare no competing financial interests. stimulating hormone and luteinizing hormone (LH), which regulate gonadal functions. Gonadal steroids feed back to regulate GnRH release. Estradiol, via estrogen receptor $\alpha(\mathrm{ER} \alpha)$, plays crucial roles in providing both negative and positive feedback to $\mathrm{GnRH} / \mathrm{LH}$ release (Moenter et al., 1990; Christian et al., 2008; Glanowska et al., 2012). In females, low estradiol levels through most of the reproductive cycle provide negative feedback, whereas when estradiol levels are high during the preovulatory phase of the cycle, estradiol feedback action switches to positive to initiate a surge of

Correspondence should be addressed to Dr. Suzanne M. Moenter, Department of Molecular and Integrative Physiology, University of Michigan, 7725 Med Sci II, 1137 E. Catherine Street, Ann Arbor, MI 48109-5622. E-mail: smoenter@umich.edu.

DOI:10.1523/JNEUROSCI.2428-17.2017

Copyright $\odot 2018$ the authors $\quad 0270-6474 / 18 / 381061-12 \$ 15.00 / 0$ 
GnRH/LH release, ultimately causing ovulation (Christian and Moenter, 2010). As GnRH neurons typically do not express detectable $\mathrm{ER} \alpha$ (Hrabovszky et al., 2001), estradiol feedback is likely transmitted to these cells by $\mathrm{ER} \alpha$-expressing afferents.

Kisspeptin-producing neurons in the anteroventral periventricular (AVPV) and arcuate nucleus are estradiol-sensitive GnRH afferents (Lehman et al., 2010; Kumar et al., 2015; Yip et al., 2015). Kisspeptin is a potent stimulator of GnRH neurons, and its expression is differentially regulated in these nuclei by estradiol (Han et al., 2005; Messager et al., 2005; Smith et al., 2005; Pielecka-Fortuna et al., 2008). AVPV kisspeptin neurons were postulated as positive feedback mediators as kisspeptin expression is increased (Smith et al., 2005). Subsequent studies demonstrated that these neurons are more excitable during positive feedback compared with negative feedback, a shift mediated by estradiol (Zhang et al., 2013; Wang et al., 2016). ER $\alpha$ in kisspeptin cells is required for positive feedback, as kisspeptin-specific ER $\alpha$ knock-out (KERKO) mice do not exhibit estradiol-induced LH surges (Mayer et al., 2010; Dubois et al., 2015; Greenwald-Yarnell et al., 2016). Arcuate kisspeptin neurons are also known as KNDy neurons because of their coexpression of neurokinin $\mathrm{B}(\mathrm{NKB})$ and dynorphin (Lehman et al., 2010). NKB and dynorphin, respectively, increase and decrease firing rate of these cells (Ruka et al., 2013; Qiu et al., 2016). KNDy neurons have been postulated to generate episodic $\mathrm{GnRH}$ release and to mediate steroid negative feedback on GnRH release frequency (Lehman et al., 2010; Vanacker et al., 2017). The mechanisms through which these two populations of kisspeptin neurons are differentially regulated by estradiol are not fully understood.

In this regard, the network upstream of the kisspeptin-to$\mathrm{GnRH}$ neuron link is largely unstudied. Activation of ionotropic glutamate receptors is needed to generate both pulse and surge modes of LH release (López et al., 1992; Brann, 1995; Ping et al., 1997). GnRH neurons, however, appear to receive limited ionotropic glutamate input (Christian et al., 2009; Iremonger et al., 2010), suggesting that GnRH afferents may be the recipients of the transmission involved in estradiol feedback. Estradiol increases expression of ionotropic glutamate receptor mRNA in AVPV neurons (Gu et al., 1999) and glutamatergic projections from the AVPV to GnRH neurons (Ottem et al., 2004). Glutamate also regulates several processes in the arcuate nucleus (Belousov and van den Pol, 1997), where KNDy neurons reside. We thus hypothesized that ionotropic glutamatergic transmission to these two kisspeptin populations is differentially regulated via cycle-dependent changes in circulating estradiol levels. KNDy neurons use glutamate as a cotransmitter (Cravo et al., 2011) and form a complex network as they synapse on each other, as well as on AVPV kisspeptin neurons (Yip et al., 2015; Qiu et al., 2016). We thus further tested whether glutamatergic transmission to kisspeptin neurons, firing rate of these neurons and in vivo output of the reproductive neuroendocrine system are disrupted in mice lacking $\mathrm{ER} \alpha$ in kisspeptin cells (KERKO).

\section{Materials and Methods}

All chemicals were purchased from Sigma unless noted.

Animals. Adult female mice aged $60-120 \mathrm{~d}$ were used for these studies. All mice were provided with water and Harlan 2916 chow (VetOne) ad libitum and were held on a $14 \mathrm{~h}$ light/10 h dark light cycle with lights on at 0400 Eastern Standard Time. To delete ER $\alpha$ specifically from kisspeptin cells, mice with Cre recombinase gene knocked-in after the Kiss1 promoter (Kiss1-Cre mice) were crossed with mice with a floxed Esr1 gene, which encodes ER $\alpha$ (ER $\alpha$ floxed mice) (Greenwald-Yarnell et al., 2016). The expression of Cre recombinase mediates deletion of $\mathrm{ER} \alpha$ in all kisspeptin cells (KERKO mice). To visualize kisspeptin neurons for record- ing, mice heterozygous for both Kiss1-Cre and floxed ER $\alpha$ were crossed with Cre-inducible YFP mice. Crossing mice heterozygous for all three alleles yielded litters that contained some mice that were homozygous for floxed $\mathrm{ER} \alpha$ and at least heterozygous for both Kiss1-Cre and YFP; these were used as KERKO mice. Littermates of KERKO mice with wild-type Esr1, Kiss1-Cre YFP, or Kiss1-hrGFP mice (Cravo et al., 2011) were used as controls; no differences were observed among these controls, and they were combined. The University of Michigan Institutional Animal Care and Use Committee approved all procedures.

To study the role of naturally fluctuating ovarian steroids, Kiss1-hrGFP mice were used during the diestrous, proestrous, or estrous phases of the estrous cycle as determined by monitoring vaginal cytology for at least a week before experiments. Uterine mass was determined to confirm uteri on proestrus were $>100 \mathrm{mg}$, indicating exposure to high endogenous estradiol (Shim et al., 2000). Ovary-intact KERKO mice have disrupted estrous cycles with persistent cornified vaginal cytology typical of estrus; we thus used females in estrus as controls. To examine the role of ovarian estradiol, mice were ovariectomized (OVX) under isoflurane anesthesia (Abbott) and were either simultaneously implanted with a SILASTIC (Dow-Corning) capsule containing $0.625 \mu \mathrm{g}$ of estradiol suspended in sesame oil $(\mathrm{OVX}+\mathrm{E})$ or not treated further (OVX) (Christian et al., 2005). Bupivacaine (0.25\%, APP Pharmaceuticals) was provided local to the incisions as an analgesic. These mice were studied $2-3 \mathrm{~d}$ after ovariectomy in the late afternoon, which is the time of estradiol-positive feedback (Christian et al., 2005).

Slice preparation and cell identification. All solutions were bubbled with $95 \% \mathrm{O}_{2} / 5 \% \mathrm{CO}_{2}$ throughout the experiments and for at least $30 \mathrm{~min}$ before exposure to tissue. The brain was rapidly removed (1500-1600 Eastern Standard Time; Zeitgeber time 10-11) and placed in ice-cold sucrose saline solution containing the following (in $\mathrm{mM}$ ): 250 sucrose, 3.5 $\mathrm{KCl}, 26 \mathrm{NaHCO}_{3}, 10$ D-glucose, $1.25 \mathrm{Na}_{2} \mathrm{HPO}_{4}, 1.2 \mathrm{MgSO}_{4}$, and 3.8 $\mathrm{MgCl}_{2}$ (pH 7.6, $\left.345 \mathrm{mOsm}\right)$. Coronal $(300 \mu \mathrm{m})$ slices were cut with a VT1200S (Leica Biosystems). Slices were incubated in a 1:1 mixture of sucrose saline and ACSF containing the following (in mM): $135 \mathrm{NaCl}, 3.5$ $\mathrm{KCl}, 26 \mathrm{NaHCO}_{3}, 10$ D-glucose, $1.25 \mathrm{Na}_{2} \mathrm{HPO}_{4}, 1.2 \mathrm{MgSO}_{4}, 2.5 \mathrm{CaCl}_{2}$ ( $\mathrm{pH} 7.4,310 \mathrm{mOsm})$ for $30 \mathrm{~min}$ at room temperature $\left(\sim 21^{\circ} \mathrm{C}-23^{\circ} \mathrm{C}\right)$ and then transferred to $100 \%$ ACSF for additional $30-180 \mathrm{~min}$ at room temperature before recording. For recording, slices were placed into a chamber continuously perfused with ACSF at a rate of $3 \mathrm{ml} / \mathrm{min}$ with oxygenated ACSF heated to $30^{\circ} \mathrm{C}-31^{\circ} \mathrm{C}$ with an inline heating unit (Warner Instruments). GFP-positive kisspeptin neurons were identified by brief illumination at $488 \mathrm{~nm}$ on an Olympus BX51WI microscope. Recorded cells were mapped to an atlas (Paxinos and Franklin, 2001) to determine whether any trends based on anatomical location emerged; no such trends were apparent in these data sets. Recordings were performed from 1 to $3 \mathrm{~h}$ after brain slice preparation, except for KERKO mice (up to $6 \mathrm{~h}$ ). No more than three cells per animal were included for analysis of the same parameter, and at least 5 animals were tested per parameter. Values toward both ends of the data distribution were observed within the same animal, and the variance of the data was no smaller within an animal than among animals.

Electrophysiological recordings. Recording micropipettes were pulled from borosilicate capillary glass (Type 7052, $1.65 \mathrm{~mm}$ outer diameter; $1.12 \mathrm{~mm}$ inner diameter; World Precision Instruments) using a Flaming/ Brown P-97 puller (Sutter Instruments) to obtain pipettes with a resistance of 3-4 $\mathrm{M} \Omega$ for extracellular and whole-cell recordings when filled with the appropriate pipette solution. Recording pipettes were wrapped with Parafilm to reduce capacitive transients; remaining transients were electronically cancelled. Recordings were made with an EPC-10 dual patch-clamp amplifier and Patchmaster software (HEKA Elektronik) running on a Macintosh computer.

Extracellular recordings. Targeted extracellular recordings were made to obtain firing properties of cells without any receptor or channel blockers. This method was used as it maintains internal milieu and has minimal impact on the firing rate of neurons (Nunemaker et al., 2003; Alcami et al., 2012). Recording pipettes were filled with HEPES-buffered solution containing the following (in mM): $150 \mathrm{NaCl}, 10$ HEPES, D-10 glucose, $2.5 \mathrm{CaCl}_{2}, 1.3 \mathrm{MgCl}_{2}$, and $3.5 \mathrm{KCl}(\mathrm{pH} 7.4,310 \mathrm{mOsm})$, and low-resistance $(<20 \mathrm{~m} \Omega)$ seals were formed between the pipette and 
neuron after first exposing the pipette to the slice tissue in the absence of positive pressure. Recordings were made in voltage-clamp mode with a 0 $\mathrm{mV}$ pipette holding potential for $20 \mathrm{~min}$ and signals acquired at $10 \mathrm{kHz}$ and filtered at $5 \mathrm{kHz}$. Resistance of the loose seal was checked every $5 \mathrm{~min}$ during the $20 \mathrm{~min}$ recordings; data were not used if seal resistance changed $>30 \%$ or was $>20 \mathrm{M} \Omega$. The first and last 5 min recording is to determine whether seal resistance is stable ( $<20 \%$ change). We used the middle $10 \mathrm{~min}$ of recording to determine the spontaneous firing frequency.

Whole-cell recordings. All recordings were done with a physiologic pipette solution containing the following (in $\mathrm{mm}$ ): $135 \mathrm{~K}$ gluconate, $10 \mathrm{KCl}$, 10 HEPES, 5 EGTA, $0.1 \mathrm{CaCl}_{2}$, $4 \mathrm{MgATP}$, and $0.4 \mathrm{NaGTP}$, pH 7.3 with $\mathrm{NaOH}, 300$ mOsm. All potentials reported were corrected online for liquid junction potential of $-15.7 \mathrm{mV}$. After achieving a minimum 2.5 $\mathrm{G} \Omega$ seal and then the whole-cell configuration, membrane potential was held at $-70 \mathrm{mV}$ between protocols during voltage-clamp recordings. Series resistance ( $<20 \mathrm{~m} \Omega,<20 \%$ change during the recording period) and the passive properties of the neuron (input resistance $>400 \mathrm{M} \Omega$, membrane capacitance stable, and holding current absolute value $<50$ pA) were monitored every $2 \mathrm{~min}$ from the current resulting from a $5 \mathrm{mV}$ hyperpolarizing voltage step from $-70 \mathrm{mV}$ (mean of 16 repeats, $20 \mathrm{~ms}$ duration); our algorithm for determining passive properties and series resistance discards traces with synaptic activity during this protocol. There was no difference in $\mathrm{I}_{\text {hold }}, \mathrm{C}_{\mathrm{m}}$, or $\mathrm{R}_{\mathrm{s}}$ among any comparisons. As reported previously (Wang et al., 2016), $\mathrm{R}_{\text {in }}$ in AVPV kisspeptin neurons is lower on diestrus than proestrus (diestrus, $\mathrm{R}_{\text {in }}=739 \pm 82 \mathrm{M} \Omega$; proestrus, $\mathrm{R}_{\mathrm{in}}=1136 \pm 83 \mathrm{M} \Omega ; p=0.003$ ). No differences in $\mathrm{R}_{\text {in }}$ were observed in arcuate kisspeptin neurons among groups.

To record spontaneous AMPA-mediated EPSCs, membrane potential was held at $-68 \mathrm{mV}$, the calculated reversal potential of $\mathrm{Cl}^{-}$based on $\mathrm{Cl}^{-}$concentration in pipette solution versus ACSF, $\mathrm{Cl}^{-}$activity coefficient (DeFazio et al., 2014), and the recording temperature. We did not use picrotoxin or other $\mathrm{GABA}_{\mathrm{A}}$ receptor blockers to avoid disinhibitory effects on the circuitry that is preserved within the slices. No PSCs were observed at a holding potential of -65 to $-70 \mathrm{mV}$ after $10 \mu \mathrm{M} C N Q X$ application to block AMPA receptors; outward $\mathrm{GABA}_{\mathrm{A}}$ receptor-mediated PSCs were observed when membrane potential was depolarized beyond $-60 \mathrm{mV}$, and inward $\mathrm{GABA}_{\mathrm{A}}$ receptor-mediated PSCs were observed when membrane potential was hyperpolarized beyond $-70 \mathrm{mV}(n=4$ for both AVPV and arcuate). For recording AMPA receptor-mediated mEPSCs, membrane potential was held at $-68 \mathrm{mV}$ and ACSF contained picrotoxin $(100 \mu \mathrm{M}), \operatorname{APV}(20 \mu \mathrm{M}$, Tocris $)$, and TTX $(1 \mu \mathrm{M}$, Tocris). In this case, TTX blockade of action potentials eliminates concerns regarding disinhibition.

Arcuate kisspeptin neurons are a potential source of glutamate transmission to one another (Cravo et al., 2011) as well as to AVPV neurons (Qiu et al., 2016); projections among arcuate kisspeptin neurons are more likely to be preserved in a slice. Dynorphin can inhibit firing activity of arcuate kisspeptin neurons (Ruka et al., 2013); we thus tested the effect of dynorphin on sEPSCs and mEPSCs of arcuate kisspeptin neurons. Dynorphin A ( $1 \mu \mathrm{M}$, Tocris) was bath-applied to the brain slices from control OVX female and KERKO OVX and OVX+E female for 5 min. Both sEPSCs and mEPSCs were recorded as above before and during dynorphin treatment, and during subsequent washout.

Tail-tip blood collection All adult female mice were ovary-intact and handled $>2$ weeks before experiments. Vaginal cytology of control and KERKO mice was determined for $>10 \mathrm{~d}$ before sampling. As KERKO mice exhibit prolonged cornification typical of estrus, control mice displaying regular 4 or $5 \mathrm{~d}$ cycles were sampled during estrus. Repetitive tail-tip blood collecting was performed as described previously $(n=6$ each control and KERKO) (Czieselsky et al., 2016). After the excision of the very tip of the tail, mice were put on a cage top and tail blood $(6 \mu \mathrm{l})$ was collected every $6 \mathrm{~min}$ for $2 \mathrm{~h}$ from 1300 to 1500 . Each time, the tail was wiped clean and then massaged for $\sim 10$ s until $6 \mu$ l blood sample was collected with a pipette tip. Whole blood was immediately diluted in $54 \mu \mathrm{l}$ of $0.1 \mathrm{M}$ PBS with $0.05 \%$ Tween 20 and homogenized and then kept on ice. Samples were stored at $-20^{\circ} \mathrm{C}$ for a subsequent ultrasensitive $\mathrm{LH}$ assay. Intra-assay CV is $2.2 \%$. Interassay coefficients of variation were 7.3\% (low quality control [QC], $0.13 \mathrm{ng} / \mathrm{ml}$ ), 5.0\% (medium QC, 0.8
Table 1. Integrative DNA technologies qPCR assays for pituitary gene expression

\begin{tabular}{lllllc}
\hline Gene & IDT assay ID & RefSeq no. & Exons & $\begin{array}{l}\text { Amplicon } \\
\text { size, bp }\end{array}$ & $\begin{array}{l}\text { Amplicon } \\
\text { location, bp }\end{array}$ \\
\hline Gapdh & Mm.PT.39.1 & NM_008084 & $2-3$ & 140 & $250-389$ \\
Actb & Mm.PT.39a.22214843.g & NM_007393 & $5-6$ & 147 & $1057-1203$ \\
Kiss1r & Mm.PT.49a.16255718.g & NM_053244 & $5-5$ & 76 & $2626-2701$ \\
Gnrhr & Mm.PT.45.16240237 & NM_010323 & $1-2$ & 93 & $573-665$ \\
Npffr1 & Mm.PT.49a.12363343 & NM_001177511 & $3-4$ & 128 & $342-469$ \\
Lhb & Mm.PT.45.5612498 & NM_008497 & $2-3$ & 91 & $137-227$ \\
Fshb & Mm.PT.45.17694677 & NM_008045 & $1-2$ & 104 & $2-105$ \\
Cga & Mm.PT.58.31855537 & NM_009889 & $1-2$ & 109 & $33-141$ \\
Egr1 & Mm.PT.45.13313108 & NM_007913 & $1-2$ & 115 & $523-637$ \\
Fst & Mm.PT.45.6344184 & NM_008046 & $5-6$ & 88 & $1295-1382$ \\
\hline
\end{tabular}

Table 2. Statistical parameters for one-way ANOVA or Kruskal-Wallis test parameters for comparison among groups

\begin{tabular}{lll}
\hline & Parameter (figure) & Diestrus, proestrus, estrus and KERKO \\
\hline AVPV & sEPSC frequency (Fig. 1C) & Kruskal-Wallis statistic $=16.8^{* * *}$ \\
& sEPSC amplitude (Fig. 1D) & Kruskal-Wallis statistic $=3.9$ \\
& mEPSC frequency (Fig. 1C) & $F_{(3,38)}=3.259^{*}$ \\
Arcuate nucleus & mEPSC amplitude (Fig. 1D) & $F_{(3,38)}=1.85$ \\
& sEPSC frequency (Fig. 3C) & Kruskal-Wallis statistic $=25.8^{* * *}$ \\
& sEPSC amplitude (Fig. 3D) & $F_{(3,43)}=0.2087$ \\
& mEPSC frequency (Fig. 3C) & $F_{(3,39)}=43.5^{* *}$ \\
& mEPSC amplitude (Fig. 3D) & $F_{(3,39)}=0.7656$ \\
\hline
\end{tabular}

${ }^{*} p<0.05 ;{ }^{* *} p<0.01 ;{ }^{* * *} p<0.001$.

Table 3. Statistical parameters for two-way ANOVA test parameters for comparison among groups: OVX and OVX + E treatment of control and KERKO mice

\begin{tabular}{|c|c|c|c|}
\hline Parameter (figure) & Estradiol & Genotype & Interaction \\
\hline \multicolumn{4}{|l|}{ AVPV } \\
\hline SEPSC frequency (Fig. 20) & $F_{(1,37)}=6.4^{*}$ & $F_{(1,37)}=0.2$ & $F_{(1,37)}=2.5$ \\
\hline sEPSC amplitude (Fig. 2D) & $F_{(1,37)}=0.1$ & $F_{(1,37)}=0.3$ & $F_{(1,37)}=0.1$ \\
\hline mEPSC frequency (Fig. 2C) & $F_{(1,36)}^{(1,3 /)}=1.8$ & $F_{(1,36)}^{(1,3 /)}=0.4$ & $F_{(1,36)}^{(1,3 /)}=3.4$ \\
\hline mEPSC amplitude (Fig. 2D) & $F_{(1,36)}=1.1$ & $F_{(1,36)}=2.2$ & $F_{(1,36)}=0.03$ \\
\hline \multicolumn{4}{|l|}{ Arcuate nucleus } \\
\hline sEPSC frequency (Fig. 4C) & $F_{(1,38)}=1.1$ & $F_{(1,38)}=24.7^{* * *}$ & $F_{(1,38)}=5.8^{*}$ \\
\hline sEPSC amplitude (Fig. 4D) & $F_{(1,38)}^{(1,38)}=0.2$ & $F_{(1,38)}=1.9$ & $F_{(1,38)}=0.4$ \\
\hline mEPSC frequency (Fig. 4C) & $F_{(1,36)}<0.01$ & $F_{(1,36)}=19 \cdot 2^{* * *}$ & $F_{(1,36)}<0.01$ \\
\hline mEPSC amplitude (Fig. 4D) & $F_{(1,36)}^{(1,30)}=1.0$ & $F_{(1,36)}=0.5$ & $F_{(1,36)}^{(1,30)}=0.07$ \\
\hline \multicolumn{4}{|l|}{ Extracellular } \\
\hline Firing frequency (Fig. 6B) & $F_{(1,36)}=0.01$ & $F_{(1,36)}=14.8^{* * *}$ & $F_{(1,36)}=1.0$ \\
\hline
\end{tabular}

$\mathrm{ng} / \mathrm{ml}$ ), and 6.5\% (high QC, $2.3 \mathrm{ng} / \mathrm{ml}$ ). Functional sensitivity is 0.016 $\mathrm{ng} / \mathrm{ml}$ (Steyn et al., 2013).

Kisspeptin and GnRH challenge. At the end of the frequent sampling period, mice received a single intraperitoneal injection of kisspeptin (65.1 $\mu \mathrm{g} / \mathrm{kg}$ ) (Hanchate et al., 2012). Blood was collected before and 15 min after injection. GnRH $(150 \mu \mathrm{g} / \mathrm{kg})$ was injected $40-45 \mathrm{~min}$ after kisspeptin, with blood collected immediately before and $15 \mathrm{~min}$ after injection.

Pituitary RNA extraction and gene expression. Ovary intact control (estrous stage of the cycle) and KERKO female mice were used. Pituitaries were collected from these animals; a further set of six pituitaries was collected from animals used in recording experiments; these were preserved in RNALater (ThermoFisher) at $-20^{\circ} \mathrm{C}$ until processing. No differences were observed between these and freshly processed pituitaries, and they were combined for analyses. Tissues were homogenized in QIAGEN RLT using pellet pestles (BioMasher II, Kimble Chase). RNA was extracted (with on-column DNasing) using RNeasy spin columns (QIAGEN). Sample RNAs (500 ng) and a standard curve of pooled mouse pituitary RNAs $(1000,200,40$, and $8 \mathrm{ng})$ were reverse-transcribed using Superscript III (20 $\mu$ l reaction volume, ThermoFisher) (Ruka et al., 
2013). All cDNA was assayed in duplicate for candidate gene mRNAs by hydrolysis probebased quantitative PCR chemistry (TaqMan, ThermoFisher). A final concentration of 1 $\mathrm{ng} / \mu \mathrm{l} \mathrm{cDNA}$ for unknowns was used for all genes, except Fst and Npffr1, which required $10 \mathrm{ng} / \mu \mathrm{l}$. The standard curves were similarly diluted. TaqMan primer-probes for mRNAs of pituitary genes (Kiss1r, Gnrhr, Lhb, Fshb, Cga, Egr1, Fst, Npffr1) and housekeeping mRNAs Gapdh and Actb were purchased from Integrative DNA Technologies (Table 1).

Primer probes were resuspended in TrisEDTA to $20 \times(5 \mu \mathrm{m}$ each primer, $10 \mu \mathrm{m}$ probe) as recommended. qPCR was performed using cDNA as described previously (Ruka et al., 2013). In brief, $5 \mu$ l of diluted cDNA (10 or $1 \mathrm{ng} / \mu \mathrm{l}$ ) was run in duplicate using TaqMan Gene Expression Master Mix (Applied Biosystems) for 40 cycles as indicated by the manufacturer. Linearity and parallelism of the amplification were confirmed. Amplicon size was confirmed by agarose gel electrophoresis and sequencing for custom primer-probe sets.

Data analysis. Events (PSCs or action currents) were detected and visually confirmed using custom software written in Igor Pro (Wavemetrics) (Sullivan et al., 2003; DeFazio et al., 2014). Frequency is reported as the total number of confirmed events divided by the duration of recording. Superimposed events were measured from each event's baseline for amplitude; such events were excluded from analysis of event kinetics, including FWHM (ms), an average $10 \%-90 \%$ decay time $(\mathrm{ms})$, and rise time $(\mathrm{ms})$. LH pulses were detected by a version of Cluster (Veldhuis and Johnson, 1986) transferred to IgorPro using cluster sizes of 2 points for both peak and nadir and $t$ scores of 2 for detection of increases and decreases. Normalized relative gene expression was determined by the $\Delta \Delta \mathrm{Ct}$ method (Livak and Schmittgen, 2001). Gapdh gene expression was regulated between control and KERKO; relative gene expression was thus normalized to Actb. To avoid intra-assay variability, all samples were assayed within the same assay.

Experimental design and statistical analysis. Only adult female mice were used for these studies as only females exhibit estradiol-positive feedback. Our objective was to understand the switch between estradiolnegative and -positive feedback regulation in female reproduction. The sample size for each individual experiment is listed in Results. Data were analyzed using Prism 7 (GraphPad Software) and are reported as mean \pm SEM. The number of cells per group is indicated by $n$. Normality tests were performed using the Shapiro-Wilk normality test. Data were compared as dictated by distribution and experimental design; tests are specified in Results. All two-group comparisons were two-tailed. Significance was set at $p<0.05$, all $p$ values $<0.1$ are indicated in text and figures, and all $p$ values $<0.2$ are mentioned in the text. The $p$ value for any comparison made for which a specific $p$ value is not given was $\geq 0.2$. Parameters for all statistical comparisons are reported in Tables 2 and 3 or in the legends.

\section{Results}

Ionotropic AMPA-mediated glutamatergic transmission to AVPV kisspeptin neurons is increased during positive feedback (proestrus) compared with negative feedback (diestrus and estrus)

Whole-cell recordings of AMPA-mediated sEPSCs were made in the late afternoon from AVPV kisspeptin neurons in brain slices from ovary-intact control mice in different stages of the estrous cycle (diestrus, proestrus, estrus), and KERKO mice (persistent cornified vaginal cytology similar to estrus; high circulating estradiol similar to proestrus) (Greenwald-Yarnell et al., 2016). sEPSCs include both action-potential-dependent and action-potentialindependent glutamate release. Representative recordings from each cycle stage studied are shown in Figure $1 A$. Frequency of sEPSCs was higher on proestrus compared diestrus or estrus in AVPV kisspeptin neurons (Fig. $1 C ; n=11$ each, Kruskal-Wallis/ Dunn's test, diestrus vs proestrus, $p=0.006$; proestrus vs estrus, $p=0.002$; diestrus vs estrus, $p>0.99$ ).

To determine whether increased sEPSC frequency was attributable to increased presynaptic activity and/or increased synaptic release sites, mEPSCs were recorded (Fig. 1B). mEPSCs arise from the postsynaptic response to activity-independent vesicle fusion and transmitter release from the presynaptic neuron. Their frequency is proportional to a combination of the number of functional release sites and/or release probability, whereas amplitude reflects amount of glutamate release and/or postsynaptic AMPA receptor expression (Auger and Marty, 2000). Frequency of mEPSCs was higher on proestrus compared with diestrus or estrus ( $\mathrm{n}=11$ for each; one-way ANOVA/Holm-Sidak; diestrus vs proestrus, $p=0.049$; proestrus vs estrus, $p=0.06$ ), suggesting increases in release sites and/or probability during estradiol-positive feedback. On proestrus, but not diestrus or estrus, mEPSC frequency was lower than that of sEPSCs (sEPSCs, $4.5 \pm 0.5 \mathrm{~Hz}$; mEPSCs, $2.3 \pm$ $0.4 \mathrm{~Hz}$; two-way ANOVA/Holm-Sidak, $p=0.0006)$. This suggests at least some afferents of AVPV kisspeptin cells are preserved within the slices, and that the activity of these afferents is increased on proestrus by the hormonal changes of the estrous cycle. No changes in amplitude (Fig. $1 D$ ) or kinetics of sEPSCs or mEPSCs were observed among groups (Table 4).

\section{Estradiol increases glutamatergic transmission to AVPV kisspeptin neurons}

To test whether changes observed in sEPSCs and mEPSC frequency in AVPV kisspeptin neurons observed on proestrus are 
Table 4. Kinetics of sEPSCs and mEPSCs in AVPV and arcuate kisspeptin neurons; no statistic difference noticed

\begin{tabular}{|c|c|c|c|}
\hline & Rise time (ms) & FWHM (ms) & $\overline{\text { Decay (ms) }}$ \\
\hline \multicolumn{4}{|l|}{ AVPV sEPSCs } \\
\hline \multicolumn{4}{|l|}{ Ovary-intact } \\
\hline Diestrus & $0.25 \pm 0.02$ & $2.3 \pm 0.1$ & $3.6 \pm 0.2$ \\
\hline Proestrus & $0.25 \pm 0.01$ & $2.0 \pm 0.1$ & $3.2 \pm 0.1$ \\
\hline Estrus & $0.28 \pm 0.04$ & $2.3 \pm 0.1$ & $3.6 \pm 0.3$ \\
\hline KERKO & $0.27 \pm 0.04$ & $2.0 \pm 0.1$ & $3.0 \pm 0.3$ \\
\hline \multicolumn{4}{|l|}{ Control } \\
\hline OVX & $0.26 \pm 0.03$ & $2.3 \pm 0.1$ & $3.6 \pm 0.2$ \\
\hline$O V X+E$ & $0.25 \pm 0.03$ & $2.1 \pm 0.1$ & $3.3 \pm 0.2$ \\
\hline \multicolumn{4}{|l|}{ KERKO } \\
\hline OVX & $0.23 \pm 0.03$ & $2.0 \pm 0.2$ & $3.5 \pm 0.2$ \\
\hline$O V X+E$ & $0.23 \pm 0.03$ & $2.1 \pm 0.2$ & $3.8 \pm 0.4$ \\
\hline \multicolumn{4}{|l|}{ AVPV mEPSCs } \\
\hline \multicolumn{4}{|l|}{ Ovary-intact } \\
\hline Diestrus & $0.28 \pm 0.02$ & $2.7 \pm 0.2$ & $3.5 \pm 0.3$ \\
\hline Proestrus & $0.27 \pm 0.02$ & $2.5 \pm 0.2$ & $3.3 \pm 0.3$ \\
\hline Estrus & $0.21 \pm 0.03$ & $2.0 \pm 0.1$ & $3.2 \pm 0.2$ \\
\hline KERKO & $0.24 \pm 0.02$ & $2.1 \pm 0.2$ & $3.3 \pm 0.4$ \\
\hline \multicolumn{4}{|l|}{ Control } \\
\hline OVX & $0.28 \pm 0.04$ & $2.7 \pm 0.1$ & $3.9 \pm 0.3$ \\
\hline$O V X+E$ & $0.30 \pm 0.05$ & $2.1 \pm 0.1$ & $2.9 \pm 0.2$ \\
\hline \multicolumn{4}{|l|}{ KERKO } \\
\hline OVX & $0.24 \pm 0.01$ & $2.1 \pm 0.1$ & $3.7 \pm 0.3$ \\
\hline$O V X+E$ & $0.26 \pm 0.03$ & $2.2 \pm 0.4$ & $3.7 \pm 0.2$ \\
\hline \multicolumn{4}{|l|}{ Arcuate sEPSCs } \\
\hline \multicolumn{4}{|l|}{ Ovary-intact } \\
\hline Diestrus & $0.21 \pm 0.03$ & $2.5 \pm 0.2$ & $3.6 \pm 0.3$ \\
\hline Proestrus & $0.19 \pm 0.03$ & $2.1 \pm 0.1$ & $3.7 \pm 0.2$ \\
\hline Estrus & $0.18 \pm 0.03$ & $2.0 \pm 0.1$ & $4.0 \pm 0.2$ \\
\hline KERKO & $0.20 \pm 0.04$ & $2.3 \pm 0.2$ & $3.6 \pm 0.3$ \\
\hline \multicolumn{4}{|l|}{ Control } \\
\hline OVX & $0.25 \pm 0.03$ & $2.1 \pm 0.1$ & $3.4 \pm 0.2$ \\
\hline$O V X+E$ & $0.21 \pm 0.03$ & $2.1 \pm 0.1$ & $4.3 \pm 0.2$ \\
\hline \multicolumn{4}{|l|}{ KERKO } \\
\hline OVX & $0.17 \pm 0.03$ & $2.0 \pm 0.2$ & $3.8 \pm 0.6$ \\
\hline $\mathrm{OVX}+\mathrm{E}$ & $0.22 \pm 0.03$ & $2.0 \pm 0.1$ & $3.3 \pm 0.2$ \\
\hline \multicolumn{4}{|l|}{ Arcuate mEPSCs } \\
\hline \multicolumn{4}{|l|}{ Ovary-intact } \\
\hline Diestrus & $0.23 \pm 0.02$ & $2.2 \pm 0.1$ & $3.6 \pm 0.3$ \\
\hline Proestrus & $0.19 \pm 0.02$ & $2.2 \pm 0.1$ & $4.0 \pm 0.2$ \\
\hline Estrus & $0.18 \pm 0.02$ & $2.0 \pm 0.1$ & $3.8 \pm 0.2$ \\
\hline KERKO & $0.18 \pm 0.02$ & $2.4 \pm 0.2$ & $3.8 \pm 0.4$ \\
\hline \multicolumn{4}{|l|}{ Control } \\
\hline ovX & $0.24 \pm 0.04$ & $2.1 \pm 0.2$ & $3.6 \pm 0.2$ \\
\hline$O V X+E$ & $0.22 \pm 0.04$ & $2.2 \pm 0.2$ & $4.4 \pm 0.3$ \\
\hline \multicolumn{4}{|l|}{ KERKO } \\
\hline OVX & $0.24 \pm 0.03$ & $2.1 \pm 0.2$ & $3.6 \pm 0.3$ \\
\hline $\mathrm{OVX}+\mathrm{E}$ & $0.21 \pm 0.03$ & $1.9 \pm 0.2$ & $3.0 \pm 0.2$ \\
\hline
\end{tabular}

mediated by circulating estradiol, we compared sEPSC and mEPSC frequency in AVPV kisspeptin neurons from OVX and OVX $+\mathrm{E}$ mice; recordings were done in the late afternoon at the time of estradiol-induced positive feedback in $\mathrm{OVX}+\mathrm{E}$ and proestrous mice. Increased frequency of both sEPSCs and mEPSCs (Fig. $2 A-C$ ) was observed in cells from OVX $+\mathrm{E}$ versus OVX mice ( $s E P S C s, ~ n=11$ each, two-way ANOVA/Holm-Sidak, $p=0.009$; mEPSCs, $n=11$ each, two-way ANOVA/Holm-Sidak, $p=0.04$ ), suggesting that estradiol plays a role in activating afferents of AVPV kisspeptin neurons as well as remodeling synaptic release sites. No changes of amplitude (Fig. 2D) or kinetics of EPSCs were observed among groups (Table 4).
ER $\alpha$ expression in kisspeptin cells is required for regulation of glutamatergic transmission to AVPV kisspeptin neurons during the estrous cycle and by estradiol

To test the role of ER $\alpha$ expression in kisspeptin cells in glutamatergic transmission to AVPV kisspeptin neurons, we examined EPSC frequency in cells from KERKO mice. KERKO mice have persistent vaginal cornification and enlarged uteri, indicative of prolonged exposure to elevated estradiol (Greenwald-Yarnell et al., 2016). Nonetheless, sEPSC frequency in AVPV kisspeptin neurons from KERKO mice was lower than that observed on proestrus (estradiol peak during the cycle; Fig. $1 A, C ; n=11$ for KERKO, one-way ANOVA/Holm-Sidak, $p=0.02$ ). Frequency of mEPSCs in cells from KERKO mice, however, did not differ from that of diestrous or estrous mice (Fig. $1 B, C ; n=9$ for KERKO, one-way ANOVA/Holm-Sidak, $p>0.6$ for all comparisons). Deletion of $\mathrm{ER} \alpha$ from kisspeptin cells may thus alter the activity of their primary afferents but appears to have minimal effect on synaptic release sites.

To investigate whether loss of $\mathrm{ER} \alpha$ in kisspeptin cells alters estradiol regulation of glutamatergic transmission in KERKO mice, we examined EPSCs in AVPV kisspeptin neurons from OVX and OVX+E KERKO mice. In KERKO mice, estradiol failed to increase sEPSC and mEPSC frequency as it did in control mice (Fig. $2 A, C ; n=9$ for KERKO OVX and OVX+E, two-way ANOVA/Holm-Sidak). Further, in AVPV cells from KERKO mice, neither frequency nor amplitude of sEPSCs or mEPSCs was regulated by estradiol. No changes of amplitude (Fig. 2D) or kinetics of EPSCs were observed among all groups (Table 4). This suggests that ER $\alpha$ in kisspeptin cells is required for estradioldependent regulation of ionotropic glutamatergic afferents to AVPV kisspeptin neurons during the estrous cycle.

\section{Ionotropic AMPA-mediated glutamatergic transmission to arcuate KNDy neurons is decreased during positive feedback (proestrus) compared with negative feedback (diestrus or estrus)}

Estradiol differentially regulates the expression of kisspeptin in arcuate and AVPV kisspeptin neurons (Smith et al., 2005). To examine whether this differential regulation extends to physiologic properties, we monitored EPSCs in arcuate KNDy neurons. In contrast to AVPV kisspeptin neurons, sEPSC frequency in arcuate KNDy neurons was reduced on proestrus compared with diestrus or estrus (Fig. $3 A, C ; n=13$ for diestrus and proestrus, $n=12$ for estrus, Kruskal-Wallis/Dunn's test, diestrus vs proestrus, $p=0.03$; proestrus vs estrus, $p=0.04$; diestrus vs estrus, $p>$ $0.9)$. The frequency of mEPSCs was increased on estrus compared with proestrus. No difference was detected between diestrus and either proestrus or estrus (Fig. $3 B, C$; diestrus, $n=12$; proestrus and estrus, $n=11$ each; one-way ANOVA/ HolmSidak; proestrus vs estrus, $p=0.02$ ), suggesting that the number of release sites and/or release probability may increase on estrus. Altered sEPSC frequency in KNDy neurons is thus likely mediated by changes in afferent activity. No changes of amplitude (Fig. 3D) or kinetics of EPSCs were observed among all groups (Table 4).

\section{Estradiol decreases glutamatergic transmission to arcuate KNDy neurons}

To test whether cycle-mediated changes observed in glutamatergic transmission to arcuate KNDy neurons are mediated by estradiol, we compared sEPSC and mEPSC frequency in KNDy neurons from OVX versus OVX + E mice. Frequency of sEPSCs 
was lower in OVX $+\mathrm{E}$ than OVX mice (Fig. $4 A, C ; n=12$ each, two-way ANOVA/Holm-Sidak, $p=0.04)$. No changes were observed in mEPSC frequency (Fig. $4 B, C ; n=11$ each, two-way ANOVA/Holm-Sidak). This suggests that the cycle-dependent changes observed above are mostly mediated by estradiol modulation of afferent neuron firing. No changes of amplitude (Fig. 4D) or kinetics of EPSCs were observed among groups (Table 4).

ER $\alpha$ expression in kisspeptin cells is required for regulation of glutamatergic transmission to arcuate KNDy neurons during the estrous cycle and by estradiol

To test the role of ER $\alpha$ expression in kisspeptin cells in glutamatergic transmission to KNDy neurons, we examined sEPSC and mEPSC frequency in arcuate kisspeptin neurons from KERKO mice. Strikingly, the frequency of sEPSCs in cells from KERKO mice was markedly increased compared with proestrus; the $p$ values for comparisons to cells from estrous and diestrous mice approached the level set for significance (Fig. $3 A, C ; n=9$ for KERKO, Kruskal-Wallis/Dunn's, KERKO vs proestrus, $p<0.001$; KERKO vs diestrus, $p=$ 0.07 ; KERKO vs estrus, $p=0.08$ ). Frequency of mEPSCs in KNDy neurons from KERKO mice was greater than in cells from ovary-intact mice during any cycle stage (Fig. $3 B, C ; n=9$ for KERKO, one-way ANOVA/Holm-Sidak; KERKO, $p<0.001$ vs proestrus, diestrus, and estrus). These observations suggest that the lack of ER $\alpha$ in kisspeptin cells may increase glutamate release sites and/or probability.

We then tested whether estradiol regulation of glutamatergic transmission to arcuate kisspeptin neurons is altered in KERKO mice. Frequency of sEPSCs was higher in cells from OVX +E KERKO than control mice (Fig. 4A, $C$; KERKO, $n=9$ each, two-way ANOVA/Holm-Sidak, $p<$ $0.001)$ but did not differ between cells from OVX control and KERKO mice $(p=$ $0.15)$. This suggests that estradiol regulation of glutamatergic transmission to arcuate kisspeptin neurons is lost in KERKO mice. The frequency of mEPSCs in cells from KERKO mice was increased compared with controls in both OVX and OVX +E groups (Fig. $4 B, C$; KERKO, $n=9$ each, twoway ANOVA/Holm-Sidak; OVX, $p=0.04$; OVX + E, $p=0.006$ ). These findings suggest that estradiol suppresses presynaptic activity to decrease sEPSC frequency during positive feedback. In contrast, in KERKO mice, estradiol primarily increases synaptic release sites and/or release probability.

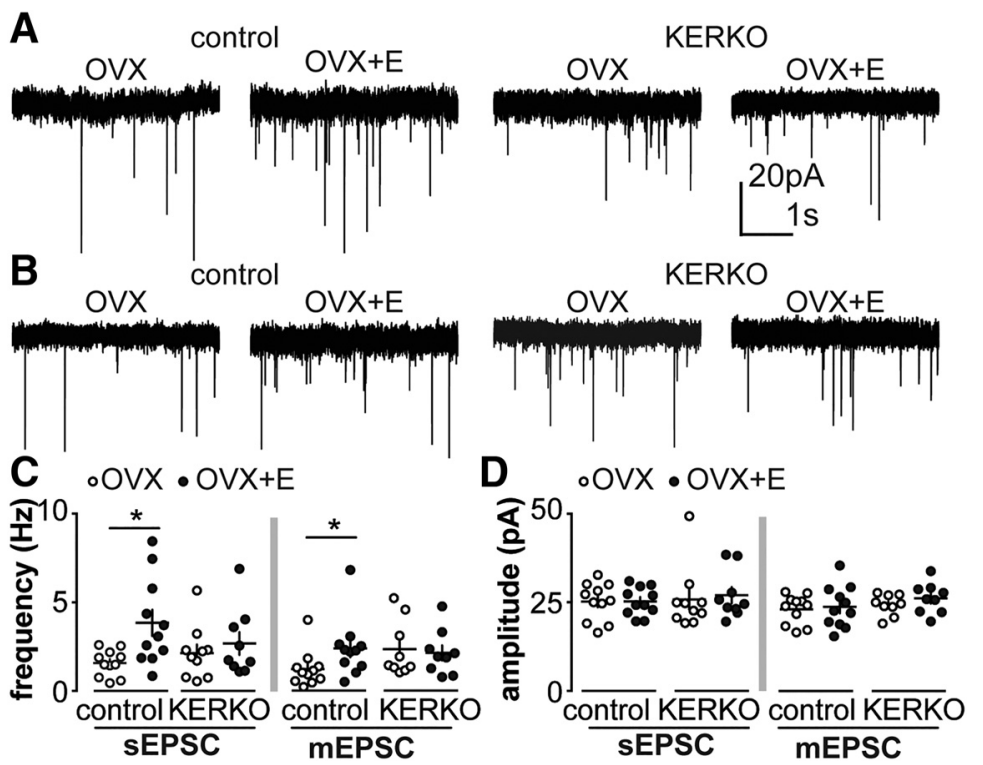

Figure 2. Estradiol does not modulate glutamatergic transmission to AVPV kisspeptin neurons from KERKO mice. $A, B$, Representative spontaneous $(\boldsymbol{A})$ and miniature $(\boldsymbol{B})$ postsynaptic currents in AVPV kisspeptin neurons in OVX and OVX+E groups in control and KERKO mice. C, Individual values and mean \pm SEM sEPSC (left) and mEPSC (right) frequency. $\boldsymbol{D}$, Individual values and mean \pm SEM sEPSC (left) and mEPSC (right) amplitude. * $p<0.05$ (two-way ANOVA/Holm-Sidak).

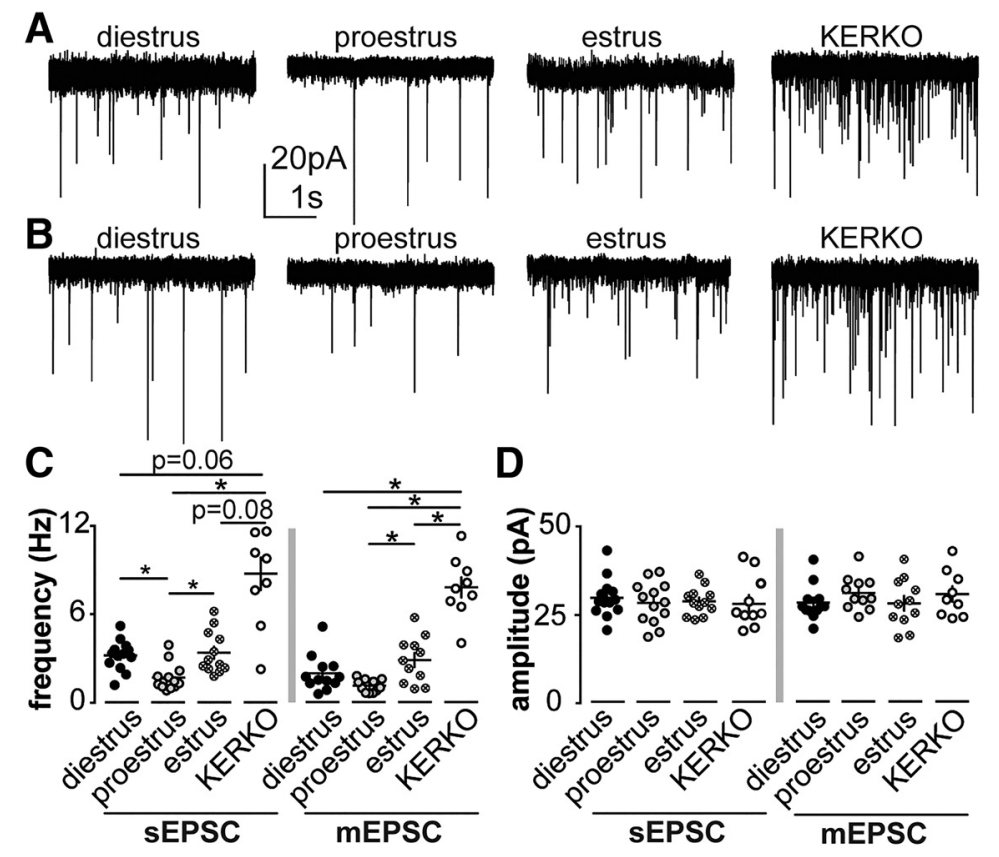

Figure 3. Estrous-cycle-dependent regulation of glutamatergic transmission to arcuate kisspeptin neurons requires ER $\alpha$ in kisspeptin cells. $\boldsymbol{A}, \boldsymbol{B}$, Representative spontaneous $(\boldsymbol{A})$ and miniature $(\boldsymbol{B})$ postsynaptic currents in arcuate kisspeptin neurons in ovary-intact control mice on diestrus, proestrus, and estrus and KERKO mice. $C$, Individual values and mean \pm SEM sEPSC (left) and mEPSC (right) frequency. D, Individual values and mean \pm SEM sEPSC (left) and mEPSC (right) amplitude. ${ }^{*} p<0.05$ (KruskalWallis/Dunn's; $C$, left) or one-way ANOVA/Holm-Sidak (the rest).

Glutamatergic transmission to arcuate KNDy neurons was suppressed by dynorphin

Previous research suggests that arcuate KNDy neurons synapse on each other (Yip et al., 2015; Qiu et al., 2016). This is of interest because most KNDy neurons are also glutamatergic (Cravo et al., 2011) and may thus serve as glutamatergic inputs to one another (Qiu et al., 2016). Dynorphin suppresses the activity of KNDy neurons (Ruka et al., 2013), as well as arcuate POMC neurons 
A

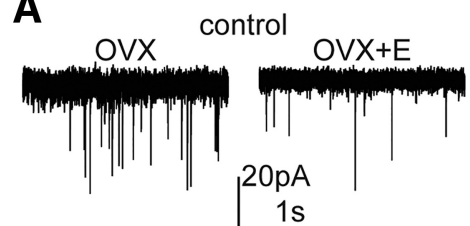

B

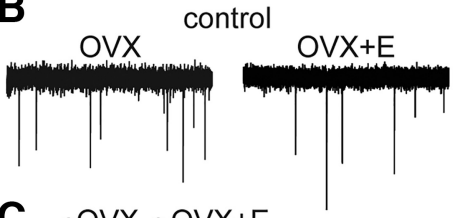

C $.0 \mathrm{VV} \cdot \mathrm{OVX}+\mathrm{E}$

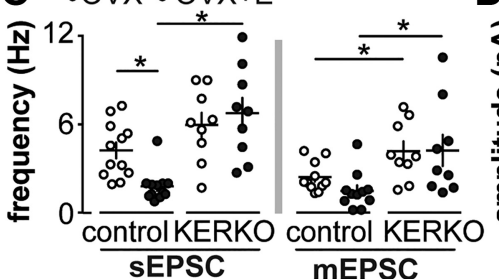

D $\quad \mathrm{OVX} \cdot \mathrm{OVX}+\mathrm{E}$

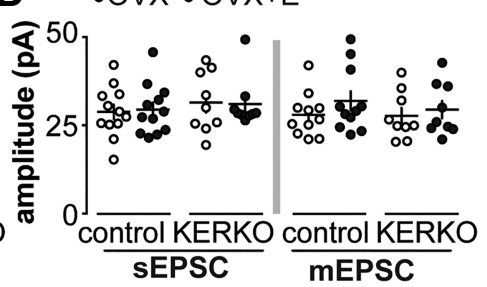

Figure 4. Estradiol does not modulate glutamatergic transmission to arcuate kisspeptin neurons from KERKO mice. $\boldsymbol{A}, \boldsymbol{B}$, Representative spontaneous $(\boldsymbol{A})$ and miniature $(\boldsymbol{B})$ postsynaptic currents in arcuate kisspeptin neurons in OVX and OVX + E groups in control and KERKO mice. $C$, Individual values and mean \pm SEM sEPSC (left) and mEPSC (right) frequency. D, Individual values and mean \pm SEM sEPSC (left) and mEPSC (right) amplitude. ${ }^{*} p<0.05$ (two-way ANOVA/ Holm-Sidak).

A
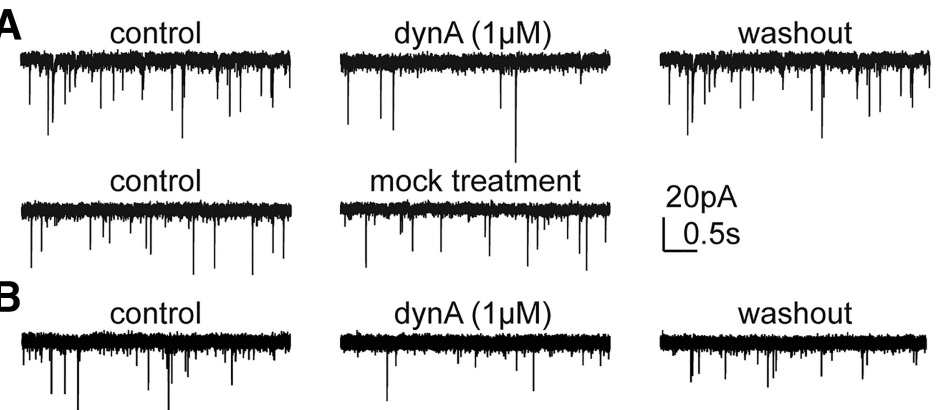

$20 \mathrm{pA}$

$\underline{0.5 \mathrm{~s}}$

B
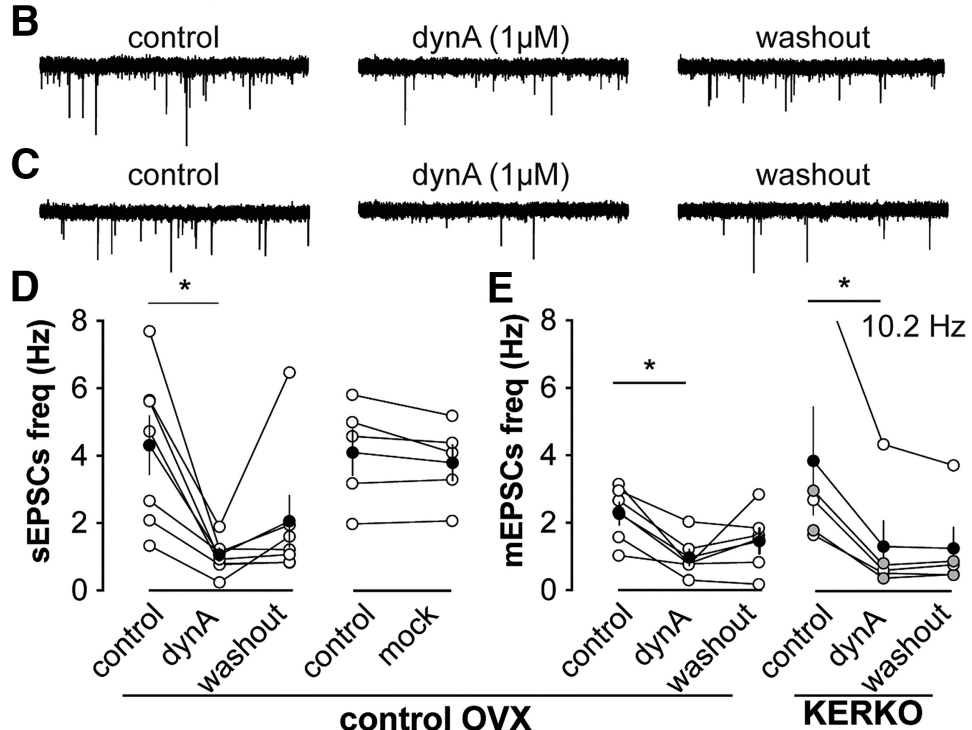

Figure 5. Dynorphin suppresses both sEPSC and mEPSCs frequency in arcuate kisspeptin neurons. $\boldsymbol{A}$, representative sEPSCs in arcuate kisspeptin neurons in OVX mice during control, dynA treatment and washout period (upper) and during control and mock treatment (lower). $\boldsymbol{B}$ and $\boldsymbol{C}$, representative mEPSCs during control, dynA treatment and washout period in arcuate kisspeptin neurons in OVX control mice $(\boldsymbol{B})$ and in OVX KERKO mice (C). D, Individual values (white) and mean \pm SEM (black) and sEPSC frequency in arcuate during control, treatment and washout (left) and during control and mock treatment (right). One data point that was out of range of the axes is indicated in text $(10.2 \mathrm{~Hz})$. For dynA treatment (left), Friedman statistic $=8.9$; for mock treatment (right), $t$ statistic $=1.5$, degrees of freedom $(\mathrm{df})=4 . \boldsymbol{E}$, Individual values (white OVX, grey OVX $+\mathrm{E}$ ) and mean $\pm \mathrm{SEM}$ (black) mEPSC frequency during control, treatment and washout in OVX control mice (left, one-way ANOVA, treatment, $F(2,10)=$ 4.9; individual, $F(5,10)=1.5$ ) and in KERKO mice (right, Friedman statistic, 7.6). ${ }^{*} p<0.05$.
(Zhang and van den Pol, 2013), a subpopulation of which $(\sim 30 \%)$ are also glutamatergic (Hentges et al., 2009; Jarvie and Hentges, 2012). We hypothesized that dynorphin decreases glutamatergic transmission to KNDy neurons. Bath application of dynorphin A $(1 \mu \mathrm{M})$ suppressed the frequency of both sEPSCs and mEPSCs to KNDy neurons within $5 \mathrm{~min}$, similar to the time required for it to suppress the firing rate of KNDy neurons (Ruka et al., 2013); this effect was reversible, and EPSC frequency was restored to control values within a 15 min washout period (Fig. $5 A, D$; sEPSCs, $n=7$, one-way repeated-measures Friedman/Dunn's, control vs treatment, $p=0.007$; Fig. $5 B, E$; mEPSCs, $n=6$, oneway repeated-measures ANOVA/HolmSidak, control vs treatment, $p=0.02$, control vs washout, $p=0.08$ ). To test whether EPSC frequency changed with duration of recording, we performed mock treatments; in these cells, EPSC frequency remained constant over a similar time period (Fig. $5 A, D$; mock vs control, sEPSCs, $n=5$, paired Student's $t$ test). Because EPSC frequency and amplitude were not different between cells from OVX and OVX $+\mathrm{E}$ KERKO mice, we combined cells from both groups to test the effects of dynorphin. As in control mice, dynorphin reduced glutamatergic transmission to arcuate KNDy neurons from KERKO mice (Fig. 5C,E; $n=5$, one-way repeated-measures Friedman/Dunn's; control vs dynorphin, $p=$ 0.02 ; control vs washout, $p=0.06$ ). Dynorphin may act on presynaptic neurons to decrease the activity-dependent glutamate release, and on presynaptic sites to suppress the release of stored glutamate. This modulation did not require ER $\alpha$ expression by kisspeptin cells.

The short-term firing frequency of KNDy neurons was not influenced by estradiol but is increased in KERKO mice

Glutamatergic transmission to KNDy neurons is increased when either estradiol or kisspeptin-specific ER $\alpha$ expression is removed. The suppression of EPSC frequency in these neurons by dynorphin suggests that these EPSCs may arise at least in part from KNDy-to-KNDy connections. We thus hypothesized that KNDy neuronal activity is modulated by estradiol and $\mathrm{ER} \alpha$ expression within kisspeptin cells. We monitored the spontaneous firing frequency of arcuate kisspeptin neurons in OVX and OVX $+\mathrm{E}$ control and KERKO mice. KNDy neurons from control mice were either quiescent or exhibited irregular firing. Interestingly, neither 
the short-term firing frequency (Fig. $6 A, B$; control, $\mathrm{n}=12$ for OVX and $\mathrm{n}=11$ for OVX +E; KERKO, $\mathrm{n}=8$ for OVX and $\mathrm{n}=9$ for OVX+E; two-way ANOVA/ Holm-Sidak) nor the percentage of firing cells (firing rate $\geq 0.01 \mathrm{~Hz}$ ) was different between OVX and OVX $+\mathrm{E}$ control mice (OVX vs OVX +E, Fisher's exact test). Firing rate in KNDy neurons from $\mathrm{OVX}+\mathrm{E}$ KERKO mice was increased compared with controls $(p=0.008)$ and approached the value set for significance in cells from OVX mice $(p=0.06)$. Estradiol did not affect the firing activity of KNDy neurons from KERKO mice (Fig. $6 A, B$ ). Further, a higher percentage of cells fired action potentials in KERKO compared with control mice (Fig. $6 C ; \chi^{2}, p=0.01$ ). In addition to increasing firing rate, the pattern of firing in cells from KERKO mice was shifted in a subgroup of cells. Specifically, 3 of 17 cells exhibited a distinct and consistent burst pattern throughout the entire $10 \mathrm{~min}$ observation window (Fig. 6D); this was not observed in control mice under any steroid condition tested or in any of our previous studies of firing in KNDy neurons (Ruka et al., 2013, 2016; Vanacker et al., 2017). The loss of ER $\alpha$ in kisspeptin cells thus elevated firing and triggered bursting in KNDy neurons; this may contribute to the increased EPSC frequency in KNDy neurons and disrupted estradiol-negative feedback regulation in KERKO mice.

$\mathrm{ER} \alpha$ in kisspeptin cells is required for pulsatile release of $\mathrm{LH}$ and pituitary response to kisspeptin

Previous work in KERKO mice has shown elevated LH levels during development but not in adults (Mayer et al., 2010; Greenwald-Yarnell et al., 2016). Further, although ER $\alpha$ in kisspeptin cells was needed for estradiol-positive feedback, ER $\alpha$ was not required for estradiol-negative feedback (Dubois et al., 2015). These studies evaluated LH in single samples. While typical in mice because of low blood volume, this method cannot detect differences in the pattern of LH release, which is reflective under most physiologic circumstances of GnRH release. We used a recently developed assay that allows measurement of LH in small quantities of tail blood to assess LH pulse frequency over $2 \mathrm{~h}$ in KERKO mice and their littermate controls on estrus (Steyn et al., 2013). Representative pulse patterns are shown in Figure $7 A, B$. Similar to previous measures using single-time-point assessment, KERKO mice exhibited similar LH-pulse amplitude and baseline compared with control mice (Fig. $7 A, B, D$ ), and there was no difference in mean LH between groups ( $\operatorname{control} n=6,0.5 \pm 0.1$ $\mathrm{ng} / \mu \mathrm{l}$ vs KERKO $n=6,0.5 \pm 0.1 \mathrm{ng} / \mu \mathrm{l}$ ). LH-pulse frequency, however, was higher in KERKO mice compared with controls (Fig. $7 C$ ). After the $2 \mathrm{~h}$ sampling period, mice were challenged with kisspeptin and $\sim 0.8$ h later with GnRH. KERKO mice did not exhibit an increase in serum LH after kisspeptin and had a reduced respond to $\mathrm{GnRH}$ versus controls (Fig. $7 E, F$ ).

To gain insight into possible mechanisms underlying the blunted LH response to kisspeptin and GnRH in KERKO mice, we examined gene expression in the pituitary from separate groups of estrous control and KERKO mice that had not undergone blood sampling (control, $n=7$; KERKO, $n=8$; Fig. $7 G$ ). Steady-state mRNA levels of selected genes were determined us- ing quantitative real-time PCR (two-tailed Student's $t$ test unless specified). Bactin (Actb) was selected as the housekeeping gene as Gapdh is known to be regulated by estradiol and age (Zou and Ing, 1998; Glanowska et al., 2014), and was differently regulated in pituitaries $(p=0.008)$. Kiss1r $(p=0.048)$, but not Gnrhr, was decreased in the pituitaries from KERKO mice. Fshb (MannWhitney $U$ test) and Cga were unchanged, whereas $L h b$ was decreased in KERKO versus control mice (Mann-Whitney $U$ test, $p=0.02$ ). For Egr1, a gene activated by GnRH and kisspeptin (Witham et al., 2013), the $p$ value approached significance for a decrease in KERKO mice $(p=0.07)$. Fst expression is typically upregulated by high-frequency GnRH pulses (Burger et al., 2002) and was increased in pituitaries from KERKO mice $(p=0.048)$. The gene encoding the gonadotropin-inhibitory hormone receptor, $N p f f r 1$, was decreased in pituitaries from KERKO mice (MannWhitney $U$ test, $p=0.01$ ).

\section{Discussion}

$\mathrm{GnRH}$ neurons form the final common pathway for control of reproduction and receive regulatory input from many sources. Estradiol feedback appears to be indirect via ER $\alpha$-expressing cells, including two hypothalamic kisspeptin populations (Oakley et al., 2009; Lehman et al., 2010). Similarly, low-frequency activation of ionotropic glutamate receptors in GnRH neurons points to an indirect effect of glutamate (Christian et al., 2008; Iremonger et al., 2010). We extended the estradiol feedback network to include glutamatergic afferents of kisspeptin neurons (Fig. 8). ER $\alpha$ is required in kisspeptin cells for estradiol regulation of glutamatergic transmission to kisspeptin neurons, and for regulation of LH release in vivo. Estradiol thus acts on multiple nodes of a broad neuroendocrine network.

AVPV kisspeptin neurons help mediate estradiol induction of the GnRH/LH surge (Oakley et al., 2009). During positive feedback (proestrus, OVX +E PM), intrinsic excitability of these neurons is increased (Zhang et al., 2013; Wang et al., 2016). The present work supports and extends these observations, demonstrating that estradiol-positive feedback increases glutamate transmission to AVPV kisspeptin neurons. Estradiol-positive feedback also suppresses hyperpolarizing GABAergic transmission to these cells (DeFazio et al., 2014), indicating that, during 
A

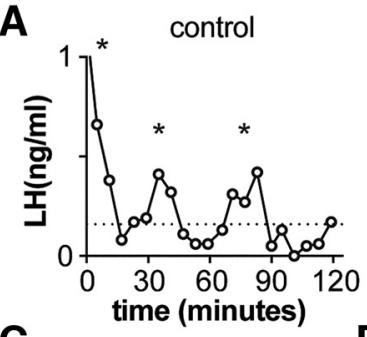

C

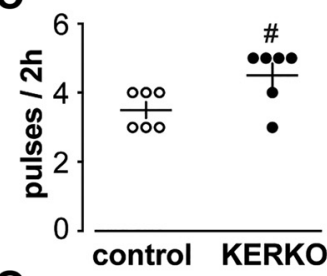

G

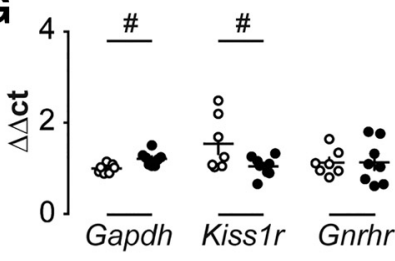

control

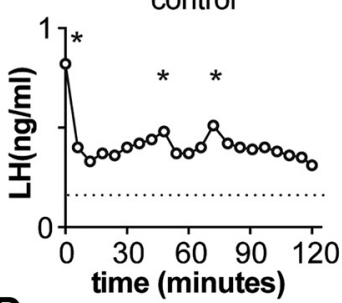

D

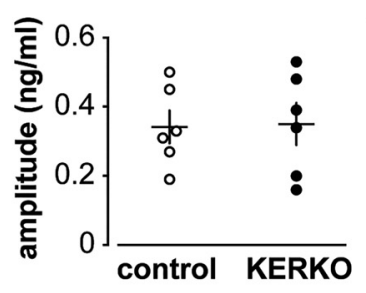

B

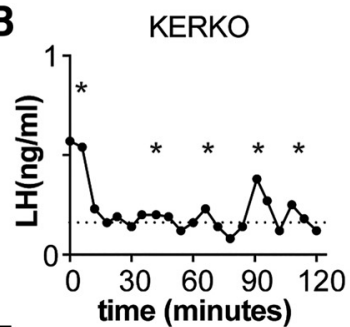

E

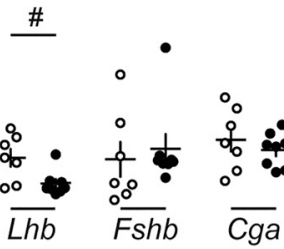

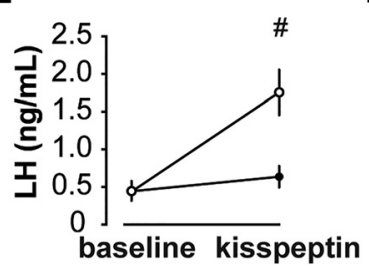

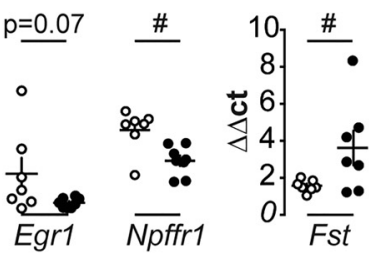

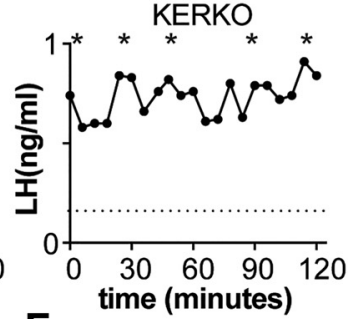

$F$

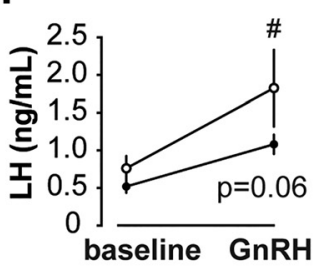

- control
- KERKO

Figure 7. ER $\alpha$ in kisspeptin cells is required for estradiol negative feedback regulation of $L H$ pulse frequency and pituitary response to kisspeptin. $A$ and $B$, representative $L H$ patterns over $2 \mathrm{~h}$ in ovary-intact estrous control $(\boldsymbol{A})$ and KERKO $(\boldsymbol{B})$ adult mice. *indicates LH pulses detected with Cluster. $\boldsymbol{C}$ and $\boldsymbol{D}$, individual values and mean \pm SEM LH pulse frequency $(\boldsymbol{C})$ and amplitude $(\boldsymbol{D})$; \#p $<$ 0.05 unpaired Student's ttest. Statistical parameters: $\boldsymbol{C}$, degrees of freedom $(\mathrm{df})=10, \mathrm{t}$ statistic $=2.5 ; \mathrm{D}$, df $=10, \mathrm{t}$ statistic $=0.1 . \boldsymbol{E}$ and $\boldsymbol{F}$, mean \pm SEM $L \mathrm{H}$ before and after IP injection of kisspeptin $(\boldsymbol{E})$ or $\mathrm{GnRH}(\boldsymbol{F}) ; \# p<0.05$ two-way repeated measures ANOVA/Holm-Sidak; statistical parameters: $\boldsymbol{E}$, treatment, $\mathrm{F}(1,10)=40.2^{*}$, genotype, $\mathrm{F}(1,10)=5.3^{*}$, interaction, $\mathrm{F}(1,10)=$ $23.4^{*} ; \boldsymbol{F}$, treatment, $\mathrm{F}(1,10)=18.3^{*}$, genotype, $\mathrm{F}(1,10)=2.0$, interaction, $\mathrm{F}(1,10)=1.8 ;{ }^{*} p<0.05$. $\boldsymbol{G}$, Individual values and mean \pm SEM normalized relative expression $(\Delta \Delta c t)$ of genes in pituitary. All gene expression was normalized to beta actin gene (Actb). $\# p<0.05$ calculated by unpaired two-tailed Student'st-test, except $L h b$, Fshb and Npffr 1 for which two-tailed Mann-Whitney U test was used. Statistical parameters: $\mathrm{df}=13$ (except Fst, df = 12); tstatistics, Gapdh, 3.2; Kiss7r, 2.2; Gnrhr, 0.02; Cga, 0.8; Egr1, 2.0; Fst, 2.2; Mann-Whitney U value, Lhb, 8.5; Fshb, 20; Npffr1, 6.
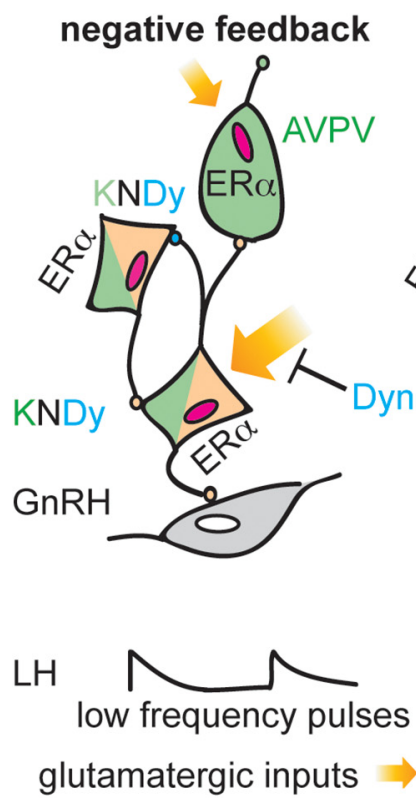

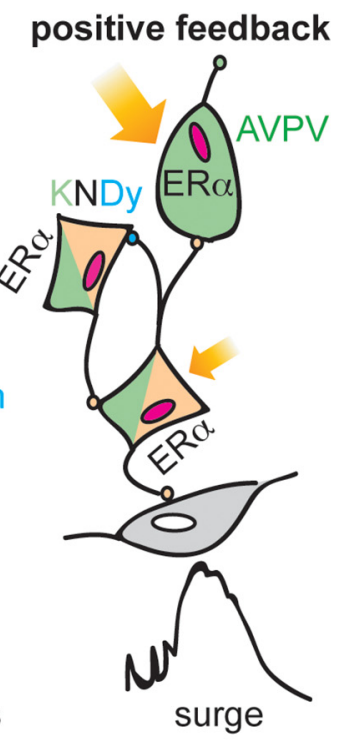

$\mathrm{ER} \alpha \mathrm{O}$

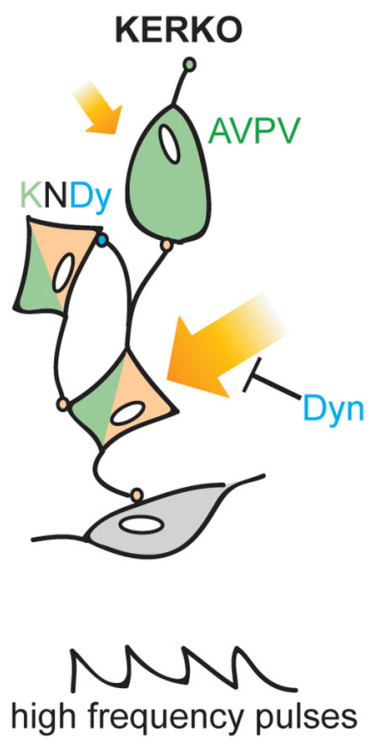

high frequency pulses

Figure 8. Schematic of estradiol feedback regulation of glutamatergic transmission to AVPV and arcuate kisspeptin neurons during negative feedback (left), positive feedback (middle), and KERKO mice (right, loss of feedback). The deletion of ER $\alpha$ from kisspeptin cells disrupts glutamatergic transmission to kisspeptin neurons and the negative feedback regulation on LH pulses.

positive feedback, estradiol tilts the balance toward excitatory inputs. Coupled with estradiol upregulation of intrinsic conductances underlying bursting firing (Wang et al., 2016), AVPV kisspeptin neurons are poised to increase output during positive feedback to drive the GnRH/LH surge.

The estradiol-induced increase in excitatory glutamatergic drive to AVPV kisspeptin neurons is attributable to at least two mechanisms: elevated presynaptic activity and changes in release sites/ probability. Activity-dependent glutamate release likely arises from cells preserved within the slice. Estradiol sensitivity of these afferents may come from their expression of estrogen receptors and/or through modifications induced by additional layer(s) of estradiol-sensitive afferents. Nearby neurons coexpressing ER $\alpha$ and vesicular glutamate transporter-2 (Eyigor et al., 2004) are candidates for direct estradiol regulation. Few AVPV kisspeptin neurons are glutamatergic (Cravo et al., 2011), and interconnections have not been reported among these cells ( $\mathrm{Ku}-$ mar et al., 2015; Yip et al., 2015), suggesting that they are unlikely to be a major source of glutamatergic drive to one another. Many AVPV kisspeptin neurons are GABAergic (Cravo et al., 2011); the concomitant increased activity of, and decreased GABAergic transmission to, these cells during positive feedback provides a functional argument against interconnections (DeFazio et al., 2014; Wang et al., 2016). The AVPV contains GABA/glutamate dual-labeled neurons; in some of these cells, the relative abundance of GABA decreases during positive feedback (Ottem et al., 
2004). The shift toward increased glutamate and reduced GABA input to AVPV kisspeptin neurons during positive feedback could thus arise from one population using both primary fast synaptic transmitters in a differential manner dependent upon estradiol feedback state.

In the AVPV, increased mEPSC frequency during positive feedback suggests that estradiol increases connectivity and/or release probability (Auger and Marty, 2000). In other regions, estradiol increases dendritic spine density, typically associated with glutamatergic synapses (Woolley, 1998; Schwarz et al., 2008). Estradiol also increases AMPA receptor subunit expression in unidentified AVPV neurons (Gu et al., 1999); the lack of change in EPSC amplitude or kinetics suggests that these changes may occur in non-kisspeptin cells. Also of interest are preoptic glutamatergic neuronal nitric oxide synthase neurons, which project to AVPV kisspeptin neurons and are regulated by kisspeptin and estradiol (Hanchate et al., 2012). Nitric oxide regulation of presynaptic glutamate release may contribute to increased glutamatergic transmission to AVPV kisspeptin neurons. KNDy neurons also release glutamate onto AVPV kisspeptin neurons (Qiu et al., 2016) and may contribute to increased mEPSCs, but not activitydependent changes as typically only processes from KNDy neurons are preserved in AVPV slices.

In contrast to AVPV kisspeptin neurons, KNDy neurons are postulated to mediate estradiol negative feedback (Lehman et al., 2010). In females, estradiol regulation of spontaneous firing of KNDy neurons is debated (de Croft et al., 2012; Cholanian et al., 2014). In short-term recordings, we observed no estradiol-induced change in firing frequency. Steroid feedback may primarily affect long-term activity patterns of these cells as in males (Vanacker et al., 2017). Estradiol did, however, suppress glutamatergic transmission to KNDy neurons, reducing sEPSC frequency. Of interest, mEPSC frequency in KNDy neurons was not regulated by estradiol (OVX vs OVX $+\mathrm{E}$ ) but was increased on estrus compared with proestrus. This change in mEPSC frequency may arise from cyclic changes in ovarian progesterone, which rises after the LH surge, or to other cycle-dependent factors. This suggests that estradiol-positive feedback reduces activity-dependent glutamate release but has minimal effects on connectivity and/or release probability.

KNDy neuron firing is modulated by two of its neuropeptide products: NKB and dynorphin (Ruka et al., 2013). Here, dynorphin potently and reversibly suppressed glutamatergic transmission to KNDy neurons, likely attributable in part to an inhibitory effect of dynorphin on presynaptic activity. Within the arcuate, KNDy ( $90 \%)$ and POMC ( 30\%) neurons are glutamatergic and express $\kappa$-opioid receptors (Cravo et al., 2011; Mercer et al., 2013; Ruka et al., 2013). Dynorphin suppresses firing of both of these populations (Ruka et al., 2013; Zhang and van den Pol, 2013). The observations that dynorphin suppresses activity of these cells and EPSC frequency in KNDy neurons suggest POMC and KNDy neurons as glutamatergic afferents of KNDy neurons. KNDy neurons synapse on each other (Yip et al., 2015; Qiu et al., 2016) and interconnect bidirectionally with POMC neurons (Manfredi-Lozano et al., 2016; Nestor et al., 2016). During proestrus, however, POMC neurons have elevated cFos expression (Cholanian et al., 2014), suggesting that they may be activated by estradiol and potentially release more glutamate. If POMC neurons were major afferents of KNDy neurons, one would expect transmission to increase, rather than decrease, during positive feedback. The dynorphin-induced decrease in mEPSC frequency in KNDy neurons suggests that dynorphin may also act as a ret- rograde messenger to inhibit activity-independent neurotransmitter release (Drake et al., 1994; Iremonger and Bains, 2009) in addition to possible effects on afferent activity.

$\mathrm{ER} \alpha$ within kisspeptin is important for regulation of reproduction. Positive feedback is disrupted in KERKO mice (Dubois et al., 2015), and kisspeptin expression is decreased in the AVPV and increased in the arcuate (Mayer et al., 2010; GreenwaldYarnell et al., 2016). Estradiol-mediated changes in glutamatergic drive to both populations were abolished in KERKO mice. Deletion of $\operatorname{ER} \alpha$ from kisspeptin cells may alter glutamatergic inputs to AVPV and arcuate kisspeptin neurons through organizational and/or activational mechanisms. ER $\alpha$ is deleted as soon as Kiss 1 is expressed, before birth in KNDy neurons and before puberty in AVPV kisspeptin neurons (Semaan et al., 2010; Kumar et al., 2014). This may cause developmental changes in the circuitry of these cells. Loss of ER $\alpha$ as a transcriptional factor may also alter expression of synapse-related genes and signaling pathways. From an activational perspective, the failure of estradiol to increase glutamatergic transmission to AVPV kisspeptin neurons in KERKO mice may indicate that glutamate afferents receive cues from kisspeptin cells through local feedback circuits. In the arcuate, both spontaneous firing frequency of, and glutamate transmission to, KNDy neurons are increased in cells from KERKO mice. These correlative observations further indicate that KNDy neurons provide glutamatergic transmission to themselves. Developmental changes subsequent to $\operatorname{ER} \alpha$ deletion in kisspeptin cells may alter activity and thus activity-dependent synaptogenesis among KNDy neurons. The observed increase in mEPSC frequency in KNDy neurons from KERKO mice is consistent with this postulate. Alternatively, but not exclusively, increased glutamate release from KNDy neurons may result in overall increased KNDy neuron firing frequency and, in some cases, acquisition of a burst firing pattern.

Ultimately, changes in hypothalamic kisspeptin neurons may affect GnRH neuron activity and pituitary LH release. The increase in LH pulse frequency in KERKO versus control mice is consistent with increased neuroendocrine drive, possibly due to increased frequency GnRH release triggered by a KNDy network lacking negative feedback. Importantly, LH release reports the integrated output of the reproductive neuroendocrine system. The same objective criteria were used for pulse detection in both groups; subjectively, LH pulse quality looks poorer in KERKO mice. Similar degradation of LH pulse patterns occurs when GnRH frequency is high (Caraty et al., 1987; Moenter, 2015). Fst and $L h b$ are typically upregulated by high $\mathrm{GnRH}$-pulse frequencies (Burger et al., 2002; Glanowska et al., 2014). In pituitaries from KERKO mice, Fst is elevated, whereas Lhb suppressed, perhaps because supraphysiological $\mathrm{GnRH}$ pulse frequencies reduce Lhb expression (Dalkin et al., 1989). Deletion of ER $\alpha$ from kisspeptin cells and/or altered feedback from other ovarian factors may also affect pituitary gene expression. The attenuated response of pituitaries from KERKO mice to kisspeptin and GnRH may be explained by decreased Kiss $1 r$ expression in pituitary as well. The increased LH pulse frequency and altered pituitary gene expression suggest that $\mathrm{ER} \alpha$ in kisspeptin cells play a vital role in negative feedback regulation.

These studies extend the network for estradiol negative and positive feedback beyond kisspeptin neurons, demonstrating that glutamatergic transmission to hypothalamic kisspeptin neurons is a critical component these responses. ER $\alpha$ in kisspeptin cells modulates the glutamatergic network upstream of these two kisspeptin populations and sculpts central reproductive neuroendocrine output within the animal. 


\section{References}

Alcami P, Franconville R, Llano I, Marty A (2012) Measuring the firing rate of high-resistance neurons with cell-attached recording. J Neurosci 32: 3118-3130. CrossRef Medline

Auger C, Marty A (2000) Quantal currents at single-site central synapses. J Physiol 526:3-11. CrossRef Medline

Belousov AB, van den Pol AN (1997) Local synaptic release of glutamate from neurons in the rat hypothalamic arcuate nucleus. J Physiol 499:747761. CrossRef Medline

Brann DW (1995) Glutamate: a major excitatory transmitter in neuroendocrine regulation. Neuroendocrinology 61:213-225. CrossRef Medline

Burger LL, Dalkin AC, Aylor KW, Haisenleder DJ, Marshall JC (2002) $\mathrm{GnRH}$ pulse frequency modulation of gonadotropin subunit gene transcription in normal gonadotropes: assessment by primary transcript assay provides evidence for roles of $\mathrm{GnRH}$ and follistatin. Endocrinology 143: 3243-3249. CrossRef Medline

Caraty A, Locatelli A, Schanbacher B (1987) Augmentation, by naloxone, of the frequency and amplitude of LHRH pulses in hypothalamo-hypophyseal portal blood in the castrated ram. C R Acad Sci III 305:369-374. Medline

Cholanian M, Krajewski-Hall SJ, Levine RB, McMullen NT, Rance NE (2014) Electrophysiology of arcuate neurokinin B neurons in female Tac2-EGFP transgenic mice. Endocrinology 155:2555-2565. CrossRef Medline

Christian CA, Moenter SM (2010) The neurobiology of preovulatory and estradiol-induced gonadotropin-releasing hormone surges. Endocr Rev 31:544-577. CrossRef Medline

Christian CA, Mobley JL, Moenter SM (2005) Diurnal and estradioldependent changes in gonadotropin-releasing hormone neuron firing activity. Proc Natl Acad Sci U S A 102:15682-15687. CrossRef Medline

Christian CA, Glidewell-Kenney C, Jameson JL, Moenter SM (2008) Classical estrogen receptor $\alpha$ signaling mediates negative and positive feedback on gonadotropin-releasing hormone neuron firing. Endocrinology 149: 5328-5334. CrossRef Medline

Christian CA, Pielecka-Fortuna J, Moenter SM (2009) Estradiol suppresses glutamatergic transmission to gonadotropin-releasing hormone neurons in a model of negative feedback in mice. Biol Reprod 80:1128-1135. CrossRef Medline

Cravo RM, Margatho LO, Osborne-Lawrence S, Donato J Jr, Atkin S, Bookout AL, Rovinsky S, Frazão R, Lee CE, Gautron L, Zigman JM, Elias CF (2011) Characterization of Kiss1 neurons using transgenic mouse models. Neuroscience 173:37-56. CrossRef Medline

Czieselsky K, Prescott M, Porteous R, Campos P, Clarkson J, Steyn FJ, Campbell RE, Herbison AE (2016) Pulse and surge profiles of luteinizing hormone secretion in the mouse. Endocrinology 157:4794-4802. CrossRef Medline

Dalkin AC, Haisenleder DJ, Ortolano GA, Ellis TR, Marshall JC (1989) The frequency of gonadotropin-releasing hormone stimulation differentially regulates gonadotropin subunit messenger ribonucleic acid expression. Endocrinology 125:917-924. CrossRef Medline

de Croft S, Piet R, Mayer C, Mai O, Boehm U, Herbison AE (2012) Spontaneous kisspeptin neuron firing in the adult mouse reveals marked sex and brain region differences but no support for a direct role in negative feedback. Endocrinology 153:5384-5393. CrossRef Medline

DeFazio RA, Elias CF, Moenter SM (2014) GABAergic transmission to kisspeptin neurons is differentially regulated by time of day and estradiol in female mice. J Neurosci 34:16296-16308. CrossRef Medline

Drake CT, Terman GW, Simmons ML, Milner TA, Kunkel DD, Schwartzkroin PA, Chavkin C (1994) Dynorphin opioids present in dentate granule cells may function as retrograde inhibitory neurotransmitters. J Neurosci 14:3736-3750. Medline

Dubois SL, Acosta-Martínez M, DeJoseph MR, Wolfe A, Radovick S, Boehm U, Urban JH, Levine JE (2015) Positive, but not negative feedback actions of estradiol in adult female mice require estrogen receptor $\alpha$ in kisspeptin neurons. Endocrinology 156:1111-1120. CrossRef Medline

Eyigor O, Lin W, Jennes L (2004) Identification of neurones in the female rat hypothalamus that express oestrogen receptor-alpha and vesicular glutamate transporter-2. J Neuroendocrinol 16:26-31. CrossRef Medline

Glanowska KM, Venton BJ, Moenter SM (2012) Fast scan cyclic voltammetry as a novel method for detection of real-time gonadotropin-releasing hormone release in mouse brain slices. J Neurosci 32:14664-14669. CrossRef Medline
Glanowska KM, Burger LL, Moenter SM (2014) Development of gonadotropin-releasing hormone secretion and pituitary response. J Neurosci 34: 15060-15069. CrossRef Medline

Greenwald-Yarnell ML, Marsh C, Allison MB, Patterson CM, Kasper C, MacKenzie A, Cravo R, Elias CF, Moenter SM, Myers MG Jr (2016) ER $\alpha$ in Tac2 neurons regulates puberty onset in female mice. Endocrinology 157:1555-1565. CrossRef Medline

Gu G, Varoqueaux F, Simerly RB (1999) Hormonal regulation of glutamate receptor gene expression in the anteroventral periventricular nucleus of the hypothalamus. J Neurosci 19:3213-3222. Medline

Han SK, Gottsch ML, Lee KJ, Popa SM, Smith JT, Jakawich SK, Clifton DK, Steiner RA, Herbison AE (2005) Activation of gonadotropin-releasing hormone neurons by kisspeptin as a neuroendocrine switch for the onset of puberty. J Neurosci 25:11349-11356. CrossRef Medline

Hanchate NK, Parkash J, Bellefontaine N, Mazur D, Colledge WH, d'Anglemont de Tassigny X, Prevot V (2012) Kisspeptin-GPR54 signaling in mouse NO-synthesizing neurons participates in the hypothalamic control of ovulation. J Neurosci 32:932-945. CrossRef Medline

Hentges ST, Otero-Corchon V, Pennock RL, King CM, Low MJ (2009) Proopiomelanocortin expression in both GABA and glutamate neurons. J Neurosci 29:13684-13690. CrossRef Medline

Hrabovszky E, Steinhauser A, Barabás K, Shughrue PJ, Petersen SL, Merchenthaler I, Liposits Z (2001) Estrogen receptor-beta immunoreactivity in luteinizing hormone-releasing hormone neurons of the rat brain. Endocrinology 142:3261-3264. CrossRef Medline

Iremonger KJ, Bains JS (2009) Retrograde opioid signaling regulates glutamatergic transmission in the hypothalamus. J Neurosci 29:7349-7358. CrossRef Medline

Iremonger KJ, Constantin S, Liu X, Herbison AE (2010) Glutamate regulation of GnRH neuron excitability. Brain Res 1364:35-43. CrossRef Medline

Jarvie BC, Hentges ST (2012) Expression of GABAergic and glutamatergic phenotypic markers in hypothalamic proopiomelanocortin neurons. J Comp Neurol 520:3863-3876. CrossRef Medline

Kumar D, Freese M, Drexler D, Hermans-Borgmeyer I, Marquardt A, Boehm U (2014) Murine arcuate nucleus kisspeptin neurons communicate with GnRH neurons in utero. J Neurosci 34:3756-3766. CrossRef Medline

Kumar D, Candlish M, Periasamy V, Avcu N, Mayer C, Boehm U (2015) Specialized subpopulations of kisspeptin neurons communicate with $\mathrm{GnRH}$ neurons in female mice. Endocrinology 156:32-38. CrossRef Medline

Lehman MN, Coolen LM, Goodman RL (2010) Minireview: kisspeptin/ neurokinin $\mathrm{B} /$ dynorphin (KNDy) cells of the arcuate nucleus: a central node in the control of gonadotropin-releasing hormone secretion. Endocrinology 151:3479-3489. CrossRef Medline

Livak KJ, Schmittgen TD (2001) Analysis of relative gene expression data using real-time quantitative PCR and the 2- $\Delta \Delta$ CT method. Methods 25: 402-408. CrossRef Medline

López FJ, Donoso AO, Negro-Vilar A (1992) Endogenous excitatory amino acids and glutamate receptor subtypes involved in the control of hypothalamic luteinizing hormone-releasing hormone secretion. Endocrinology 130:1986-1992. CrossRef Medline

Manfredi-Lozano M, Roa J, Ruiz-Pino F, Piet R, Garcia-Galiano D, Pineda R, Zamora A, Leon S, Sanchez-Garrido MA, Romero-Ruiz A, Dieguez C, Vazquez MJ, Herbison AE, Pinilla L, Tena-Sempere M (2016) Defining a novel leptin-melanocortin-kisspeptin pathway involved in the metabolic control of puberty. Mol Metab 5:844-857. CrossRef Medline

Mayer C, Acosta-Martinez M, Dubois SL, Wolfe A, Radovick S, Boehm U, Levine JE (2010) Timing and completion of puberty in female mice depend on estrogen receptor alpha-signaling in kisspeptin neurons. Proc Natl Acad Sci U S A 107:22693-22698. CrossRef Medline

Mercer AJ, Hentges ST, Meshul CK, Low MJ (2013) Unraveling the central proopiomelanocortin neural circuits. Front Neurosci 7:19. CrossRef Medline

Messager S, Chatzidaki EE, Ma D, Hendrick AG, Zahn D, Dixon J, Thresher RR, Malinge I, Lomet D, Carlton MB, Colledge WH, Caraty A, Aparicio SA (2005) Kisspeptin directly stimulates gonadotropin-releasing hormone release via G protein-coupled receptor 54. Proc Natl Acad Sci U S A 102:1761-1766. CrossRef Medline

Moenter SM (2015) Leap of faith: does serum luteinizing hormone always accurately reflect central reproductive neuroendocrine activity? Neuroendocrinology 102:256-266. CrossRef Medline

Moenter SM, Caraty A, Karsch FJ (1990) The estradiol-induced surge of 
gonadotropin-releasing hormone in the ewe. Endocrinology 127:13751384. CrossRef Medline

Nestor CC, Qiu J, Padilla SL, Zhang C, Bosch MA, Fan W, Aicher SA, Palmiter RD, Rønnekleiv OK, Kelly MJ (2016) Optogenetic stimulation of arcuate nucleus Kiss1 neurons reveals a steroid-dependent glutamatergic input to POMC and AgRP neurons in male mice. Mol Endocrinol 30:630644. CrossRef Medline

Nunemaker CS, DeFazio RA, Moenter SM (2003) A targeted extracellular approach for recording long-term firing patterns of excitable cells: a practical guide. Biol Proced Online 5:53-62. CrossRef Medline

Oakley AE, Clifton DK, Steiner RA (2009) Kisspeptin signaling in the brain. Endocr Rev 30:713-743. CrossRef Medline

Ottem EN, Godwin JG, Krishnan S, Petersen SL (2004) Dual-phenotype GABA/glutamate neurons in adult preoptic area: sexual dimorphism and function. J Neurosci 24:8097-8105. CrossRef Medline

Paxinos G, Franklin K (2001) The mouse brain in stereotaxic coordinates, Ed 2. San Diego: Elsevier Academic.

Pielecka-Fortuna J, Chu Z, Moenter SM (2008) Kisspeptin acts directly and indirectly to increase gonadotropin-releasing hormone neuron activity and its effects are modulated by estradiol. Endocrinology 149:1979-1986. CrossRef Medline

Ping L, Mahesh VB, Bhat GK, Brann DW (1997) Regulation of gonadotropin-releasing hormone and luteinizing hormone secretion by AMPA receptors. Neuroendocrinology 66:246-253. CrossRef Medline

Qiu J, Nestor CC, Zhang C, Padilla SL, Palmiter RD, Kelly MJ, Rønnekleiv OK (2016) High-frequency stimulation-induced peptide release synchronizes arcuate kisspeptin neurons and excites GnRH neurons. eLife 5:e16246. CrossRef Medline

Ruka KA, Burger LL, Moenter SM (2013) Regulation of arcuate neurons coexpressing kisspeptin, neurokinin $\mathrm{B}$, and dynorphin by modulators of neurokinin 3 and $\kappa$-opioid receptors in adult male mice. Endocrinology 154:2761-2771. CrossRef Medline

Ruka KA, Burger LL, Moenter SM (2016) Both estrogen and androgen modify the response to activation of neurokinin- 3 and $\kappa$-opioid receptors in arcuate kisspeptin neurons from male mice. Endocrinology 157:752763. CrossRef Medline

Schwarz JM, Liang SL, Thompson SM, McCarthy MM (2008) Estradiol induces hypothalamic dendritic spines by enhancing glutamate release: a mechanism for organizational sex differences. Neuron 58:584-598. CrossRef Medline

Semaan SJ, Murray EK, Poling MC, Dhamija S, Forger NG, Kauffman AS (2010) BAX-dependent and BAX-independent regulation of Kiss1 neuron development in mice. Endocrinology 151:5807-5817. CrossRef Medline

Shim WS, Conaway M, Masamura S, Yue W, Wang JP, Kmar R, Santen RJ (2000) Estradiol hypersensitivity and mitogen-activated protein kinase expression in long-term estrogen deprived human breast cancer cells in vivo. Endocrinology 141:396-405. CrossRef Medline

Smith JT, Cunningham MJ, Rissman EF, Clifton DK, Steiner RA (2005) Regulation of Kiss1 gene expression in the brain of the female mouse. Endocrinology 146:3686-3692. CrossRef Medline

Steyn FJ, Wan Y, Clarkson J, Veldhuis JD, Herbison AE, Chen C (2013) Development of a methodology for and assessment of pulsatile luteinizing hormone secretion in juvenile and adult male mice. Endocrinology 154: 4939-4945. CrossRef Medline

Sullivan SD, DeFazio RA, Moenter SM (2003) Metabolic regulation of fertility through presynaptic and postsynaptic signaling to gonadotropinreleasing hormone neurons. J Neurosci 23:8578-8585. Medline

Vanacker C, Moya MR, DeFazio RA, Johnson ML, Moenter SM (2017) Long-term recordings of arcuate nucleus kisspeptin neurons reveal patterned activity that is modulated by gonadal steroids in male mice. Endocrinology 158:3553-3564. CrossRef Medline

Veldhuis JD, Johnson ML (1986) Cluster analysis: a simple, versatile, and robust algorithm for endocrine pulse detection. Am J Physiol 250:E486E493. CrossRef Medline

Wang L, DeFazio RA, Moenter SM (2016) Excitability and burst generation of AVPV kisspeptin neurons are regulated by the estrous cycle via multiple conductances modulated by estradiol action. eNeuro 3:e0094-116. CrossRef Medline

Witham EA, Meadows JD, Hoffmann HM, Shojaei S, Coss D, Kauffman AS, Mellon PL (2013) Kisspeptin regulates gonadotropin genes via immediate early gene induction in pituitary gonadotropes. Mol Endocrinol 27: 1283-1294. CrossRef Medline

Woolley CS (1998) Estrogen-mediated structural and functional synaptic plasticity in the female rat hippocampus. Horm Behav 34:140-148. CrossRef Medline

Yip SH, Boehm U, Herbison AE, Campbell RE (2015) Conditional viral tract tracing delineates the projections of the distinct kisspeptin neuron populations to gonadotropin-releasing hormone $(\mathrm{GnRH})$ neurons in the mouse. Endocrinology 156:2582-2594. CrossRef Medline

Zhang C, Tonsfeldt KJ, Qiu J, Bosch MA, Kobayashi K, Steiner RA, Kelly MJ, Rønnekleiv OK (2013) Molecular mechanisms that drive estradioldependent burst firing of Kiss1 neurons in the rostral periventricular preoptic area. Am J Physiol Endocrinol Metab 305:E1384-E1397. CrossRef Medline

Zhang X, van den Pol AN (2013) Direct inhibition of arcuate proopiomelanocortin neurons: a potential mechanism for the orexigenic actions of dynorphin. J Physiol 591:1731-1747. CrossRef Medline

Zou K, Ing NH (1998) Oestradiol up-regulates oestrogen receptor, cyclophilin, and glyceraldehyde phosphate dehydrogenase mRNA concentrations in endometrium, but down-regulates them in liver. J Steroid Biochem Mol Biol 64:231-237. CrossRef Medline 